\title{
Prevalence of postural hypotension in primary, community and institutional care: a systematic review and meta-analysis
}

\author{
Sinead T. J. McDonagh* ${ }^{*}$, Natasha Mejzner and Christopher E. Clark
}

\begin{abstract}
Background: Postural hypotension $(\mathrm{PH})$, the reduction in blood pressure when rising from sitting or lying 0to standing, is a risk factor for falls, cognitive decline and mortality. However, it is not often tested for in primary care. $\mathrm{PH}$ prevalence varies according to definition, population, care setting and measurement method. The aim of this study was to determine the prevalence of $\mathrm{PH}$ across different care settings and disease subgroups.

Methods: Systematic review, meta-analyses and meta-regression. We searched Medline and Embase to October 2019 for studies based in primary, community or institutional care settings reporting PH prevalence. Data and study level demographics were extracted independently by two reviewers. Pooled estimates for mean PH prevalence were compared between care settings and disease subgroups using random effects meta-analyses. Predictors of PH were explored using meta-regression. Quality assessment was undertaken using an adapted Newcastle-Ottawa Scale.

Results: One thousand eight hundred sixteen studies were identified; 61 contributed to analyses. Pooled prevalences for $\mathrm{PH}$ using the consensus definition were $17 \%\left(95 \% \mathrm{Cl}, 14-20 \% ; I^{2}=99 \%\right)$ for 34 community cohorts, 19\% (15-25\%; $\left.I^{2}=98 \%\right)$ for 23 primary care cohorts and 31\% (15-50\%; $\left.I^{2}=0 \%\right)$ for 3 residential care or nursing homes cohorts ( $P=0.16$ between groups). By condition, prevalences were $20 \%\left(16-23 \% ; I^{2}=98 \%\right)$ with hypertension ( 20 cohorts), $21 \%$ $\left(16-26 \% ;\left.\right|^{2}=92 \%\right)$ with diabetes ( 4 cohorts), $25 \%\left(18-33 \% ;\left.\right|^{2}=88 \%\right)$ with Parkinson's disease (7 cohorts) and $29 \%$ $\left(25-33 \%, I^{2}=0 \%\right)$ with dementia (3 cohorts), compared to $14 \%\left(12-17 \%, I^{2}=99 \%\right)$ without these conditions $(P<0.01$ between groups). Multivariable meta-regression modelling identified increasing age and diabetes as predictors of $\mathrm{PH}$ $\left(P<0.01, P=0.13\right.$, respectively; $\left.R^{2}=36 \%\right)$. PH prevalence was not affected by blood pressure measurement device $(P=0.65)$ or sitting or supine resting position $(P=0.24)$, however, when the definition of $\mathrm{PH}$ did not fulfil the consensus description, but fell within its parameters, prevalence was underestimated $(P=0.01)$ irrespective of study quality $(P=0.04)$.

Conclusions: $\mathrm{PH}$ prevalence in populations relevant to primary care is substantial and the definition of $\mathrm{PH}$ used is important. Our findings emphasise the importance of considering checking for $\mathrm{PH}$, particularly in vulnerable populations, to enable interventions to manage it. These data should contribute to future guidelines relevant to the detection and treatment of $\mathrm{PH}$. PROSPERO:CRD42017075423.
\end{abstract}

Keywords: Postural hypotension, Orthostatic hypotension, Prevalence, Primary care, Nursing homes, Community

\footnotetext{
* Correspondence: s.t.j.mcdonagh@exeter.ac.uk

Primary Care Research Group, University of Exeter Medical School, College of Medicine and Health, St Luke's Campus, Magdalen Road, Exeter, Devon EX1 2LU, England
}

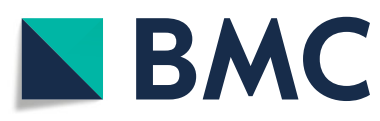

(c) The Author(s). 2021 Open Access This article is licensed under a Creative Commons Attribution 4.0 International License, which permits use, sharing, adaptation, distribution and reproduction in any medium or format, as long as you give appropriate credit to the original author(s) and the source, provide a link to the Creative Commons licence, and indicate if changes were made. The images or other third party material in this article are included in the article's Creative Commons licence, unless indicated otherwise in a credit line to the material. If material is not included in the article's Creative Commons licence and your intended use is not permitted by statutory regulation or exceeds the permitted use, you will need to obtain permission directly from the copyright holder. To view a copy of this licence, visit http://creativecommons.org/licenses/by/4.0/ The Creative Commons Public Domain Dedication waiver (http://creativecommons.org/publicdomain/zero/1.0/) applies to the data made available in this article, unless otherwise stated in a credit line to the data. 


\section{Background}

Postural, or orthostatic, hypotension $(\mathrm{PH})$, is the fall in blood pressure (BP) when rising from seated or supine to standing [1]. It is associated with an increased risk of falls, cognitive decline, reduced quality of life and mortality [2-5].

Current National Institute for Health and Care Excellence (NICE) hypertension guidelines advise testing for $\mathrm{PH}$ in the presence of type 2 diabetes, postural symptoms or aged 80 or over [6]; European guidelines also suggest checking in older people and those with diabetes [7]. Whilst $\mathrm{PH}$ is routinely tested for in primary care when symptoms are reported, we have found that it is only considered one third of the time for older people and rarely with diabetes, in the absence of symptoms [8]. Since the majority of people with $\mathrm{PH}$ are asymptomatic, they are likely to go undetected under current practices, placing them at avoidable risk of sequelae $[5,9]$.

In 2011, a consensus definition for PH: a sustained reduction in systolic BP $\geq 20 \mathrm{mmHg}$ or diastolic $\mathrm{BP} \geq 10$ $\mathrm{mmHg}$ within $3 \mathrm{~min}$ of rising to a standing position, was proposed [1]. However, many other definitions of $\mathrm{PH}$ exist; reported prevalence estimates are likely dependent on the definition used, making this a source of variance and uncertainty around diagnosis of $\mathrm{PH}$. Prevalence may also vary depending on the method of BP measurement, population and care setting under investigation. The prevalence of $\mathrm{PH}$ has been reported as ranging from 2 to $57 \%$ in community settings, primary care and institutional care cohorts [4, 10, 11]; increasing prevalences have been associated with older age, diabetes and hypertension [9, 12-14].

The large variation of reported prevalences may create uncertainty for clinicians as to who should be assessed for $\mathrm{PH}$ [15]. By describing the prevalences of $\mathrm{PH}$ in settings and conditions relevant to primary care, and identifying factors associated with greater prevalences, we aim to raise awareness of those patients most likely to have asymptomatic PH. Such evidence could counteract clinical inertia and facilitate rational choices, in the face of rising workload, as to when to invest time in testing for $\mathrm{PH}[16,17]$. Increased recognition of $\mathrm{PH}$ would permit appropriate interventions, such as review of medications, to reduce risks of falls and other sequelae [18]. We undertook the following systematic review, metaanalyses and meta-regression to address these questions.

\section{Methods}

\section{Literature searches}

A systematic review was undertaken to determine the prevalence of postural hypotension across care settings. This study was prospectively registered with PROSPERO: CRD42017075423. We searched Medline (including Medline in Process and Old Medline) and Embase from their respective commencement dates until 1st October 2019, using a broad search strategy based on key search terms (Appendix 1). Further studies were identified from the authors' archives and from reference lists of included studies and review articles. Study titles and abstracts were screened independently by two authors. Disagreements were discussed to reach consensus, with provision for adjudication by a third author, if needed. Two authors assessed and agreed full texts for inclusion, undertook data extraction and assessed study quality; the review process was managed using Covidence (Veritas Health Innovation, Melbourne, Australia).

\section{Inclusion and exclusion criteria}

Studies were eligible for inclusion if BP was measured in a lying or seated position followed by standing and using either a manual or automated sphygmomanometer. Eligible study settings were primary care, community or residential/nursing home populations. We identified 78 distinct definitions of $\mathrm{PH}$ in scoping studies for this review. To minimise heterogeneity of findings due to definitions, we restricted inclusion to studies which either reported using the consensus definition or adopted a definition encompassed within the consensus definition [1]. Exclusion criteria are summarised in Table 1.

\section{Data extraction}

Study level demographics were extracted for care setting, mean age, BP measurement device, resting position (seated or supine) and medical history of hypertension, diabetes, Parkinson's disease or dementia. Where a range of health status existed within a study population, if more than $50 \%$ of the total cohort included individuals with a particular condition, hypertension, for example, we applied the appropriate disease classification, i.e. the cohort would be classed as a hypertensive cohort. Populations were included within the community category, unless specifically selected from a primary care or institutional care setting. The Newcastle-Ottawa Scale (NOS), with questions adapted to $\mathrm{PH}$ specific context, was used to assess study quality (Appendix 2). Where multiple reports for a cohort were retrieved, extraction was primarily taken from the main publication, with addition of detail from subsidiary reports where needed.

Table 1 Exclusion criteria for review

- Definition of PH incompatible with consensus definition

- Studies where PH was provoked by tilt table testing or pain stimulation

- Studies using continuous or ambulatory BP monitoring for diagnosis of $\mathrm{PH}$

- Drug trials

- Specific but specialised cohorts, e.g. spinal injuries, multiple sclerosis or HIV

- Studies from secondary and tertiary care settings 


\section{Statistical analysis}

Pooled estimates of mean prevalences for $\mathrm{PH}$ were calculated and compared between settings and populations using meta-analysis of proportions, undertaken in Stata v16 (Statacorp, Texas, USA) [19]. Random effects models were used throughout due to anticipated heterogeneity between included studies. Statistical heterogeneity was assessed using the $\mathrm{I}^{2}$ statistic, and explored with sensitivity analyses, using meta-analysis, based on care setting, disease status or BP measurement method. We also conducted sensitivity analyses according to the definition of $\mathrm{PH}$, i.e. whether $\mathrm{PH}$ was reported using the consensus definition or a definition that fell within the consensus definition parameters but did not fully meet them (e.g. by measuring BP over less than three minutes of standing). Univariable meta-regression analyses were undertaken to examine association between study level factors [mean age, percentage of females, mean absolute resting systolic BP, care setting, BP measurement method (auscultatory or oscillometric) or position (seated or supine), disease status (hypertension, diabetes,
Parkinson's disease or dementia)] and prevalence of $\mathrm{PH}$ [20]. Factors suggesting univariable associations with $\mathrm{PH}$ (using $P<0.1$ ) were entered into multivariable models, with a priori inclusion of age, care setting and presence of diabetes and hypertension. Publication bias was assessed visually using funnel plots and quantified with the Egger test [21].

\section{Results}

Searches identified 1816 unique citations; 356 full texts were reviewed; 92 studies met inclusion criteria, but only 61 fell within the consensus definition of $\mathrm{PH}$, thus contributing to the meta-analyses. Reasons for the exclusion of studies are summarised in Fig. 1.

\section{Description of studies}

All included studies were cross-sectional or cohort studies, with cohort size ranging from 40 to 32,797 participants (Table 2). On quality assessment, areas of low quality (defined as falling below the median NOS total

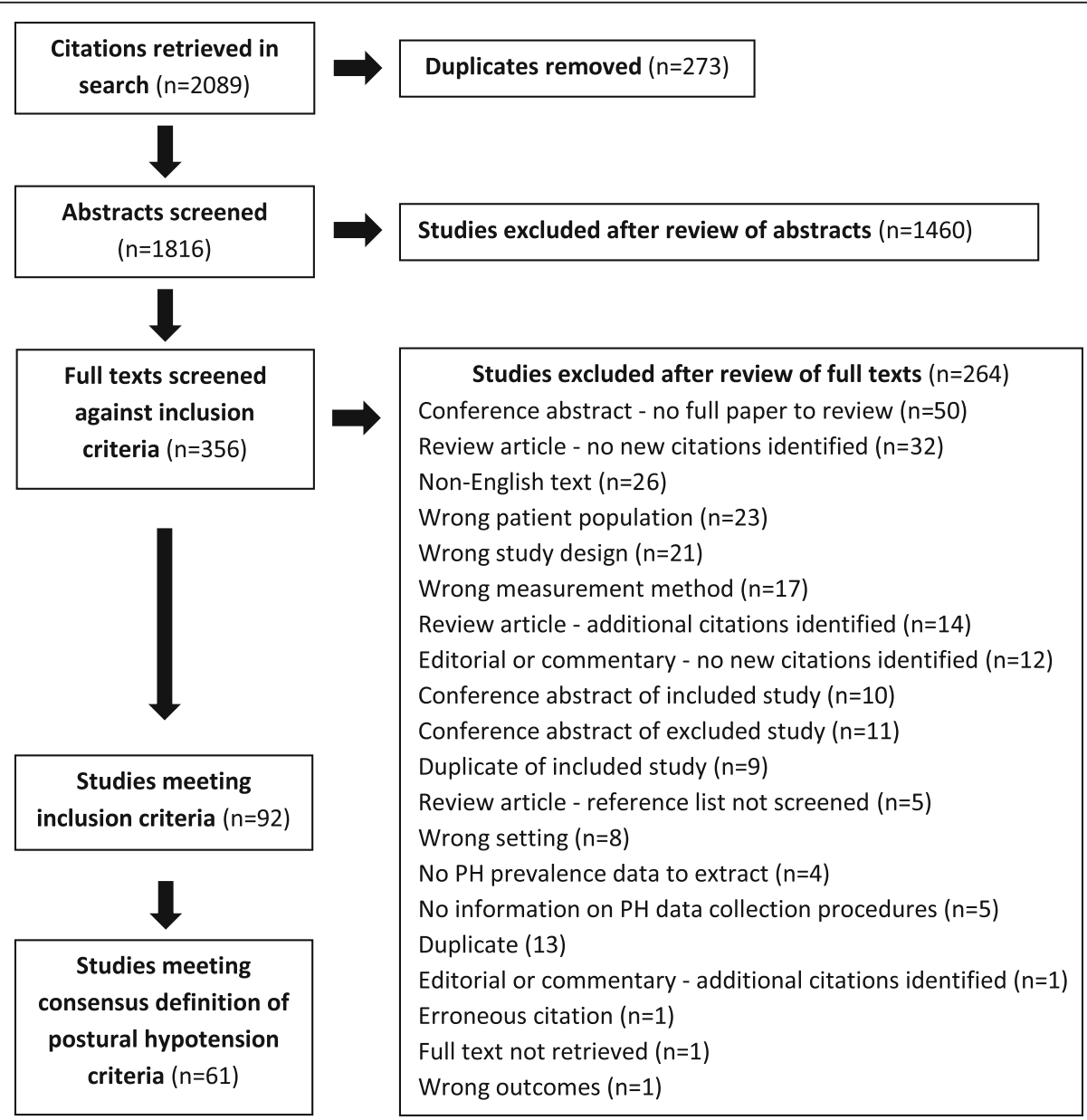

Fig. 1 Flow chart illustrating the process of inclusion or exclusion in this prevalence of postural hypotension systematic review 
Table 2 Studies included in meta-analysis for consensus definition of postural hypotension

\begin{tabular}{lll}
\hline Study & Subjects & $\begin{array}{l}\text { Age (mean or range; BP measurement method } \\
\text { years) }\end{array}$
\end{tabular}

\section{Institutional care}

\section{Reported as consensus definition of $\mathrm{PH}$}

Hommel

$2016[22]$

Male and female nursing home residents in the Netherlands, receiving long term care and using antiparkinsonian medication

\section{Not reported but fits consensus definition of $\mathrm{PH}$}

Enrique Asensio Male and female Mexican residents of public or 2011 [23] private care institutions, aged over 65 years and able to sign informed consent

Valbusa Male and female nursing home residents in

2012 [24] France and Italy, aged over 80 years and able to sign informed consent

After 10 min of supine rest and at 1 and 3 min after standing up, BP was measured using a routine sphygmomamomete

\section{Primary care}

\section{Reported as consensus definition of $\mathrm{PH}$}

Bouhanick

2014 [25]

Fleg 2016 [26]

Hirai 2009 [27]
Male and females living in France with type 2 diabetes, aged over 70 years with relatively preserved autonomy (Activity of Daily Living Score $>3 / 6$ )

Male and female participants with type 2 diabetes and a glycohaemoglobin level $\geq 7.5 \%$, aged 40-79 years with cardiovascular disease or aged 55-79years with anatomic evidence of subclinical atherosclerosis, albuminuria, left ventricular hypertrophy or $\geq 2$ additional risk factors for cardiovascular disease, attending 77 sites across the U.S.A and Canada

Male and female participants with type 1 or 2 diabetes living in Wisconsin
Male and female participants, with idiopathic Parkinson's disease, aged between 30 and 85 years old, attending a Movement Disorder Center in Italy. Participants must have been taking stable doses of dopaminergic treatment for at least 4 weeks prior to enrolment in the study

Male and female participants with first time diagnosis of mild dementia (mini mental state

Male and female participants with Parkinson's
disease (Hoehn and Yahr stage I-IV), stable on drug therapy or not received any drug attending King Chulalongkorn, Thailand

Amsterdam Dementia cohort) with subjective cognitive decline, mild cognitive impairment or Male and females with idiopathic Parkinson's disease (Hoehn and Yahr stage I-IV), aged 30-85 4 weeks prior to study enrolment, attending two specialised Movement Disorder Centres in the USA and Italy seated rest) and then once within 3
After 5 min of seated rest and at 1 and 3 min of standing up, BP was measured using an aneroid oscillometric sphygmomanometer

After 10 min of seated rest and at 1 and 3 min of standing up, BP was measured using the Colson DM-H2O automated oscillometric device (Dupont Médical, Frouard, France). All measurements were repeated three times, with intervals of 3 min on the left arm in a sitting position

After 5 min of supine rest and at 1, 3 measured. The BP device was not stated

$\mathrm{BP}$ was measured three times, at 1 min intervals, after 5 min of seated rest and on standing, using an automated oscillometric device (Omron HEM-907; Omron Healthcare Co. Kyoto, Japan)

BP was measured using a standard mercury sphygmomanometer during supine rest and repeated within 3 min after participants were asked to stand up

After 10 min of seated or supine rest, and within 3 min of standing, BP was measured using an automated sphygmomanometer (Omron HEM7200)

After 5 min of supine rest, and at 1 and 3 min after standing, $\mathrm{BP}$ was measured. The BP device was not stated

After 10 min of seated and supine rest and at 1 and 3 min after standing, BP was measured in the left arm using an automated sphygmomanometer (Omron, HEM-7200; Omron Healthcare Co. Kyoto, Japan). The average of two BP measurements were used for both seated and supine rest

BP was measured after 10 min supine 34. rest and at 1, 3 and 5 min after standing using a mercury sphygmomanometer 
Table 2 Studies included in meta-analysis for consensus definition of postural hypotension (Continued)

\begin{tabular}{|c|c|c|c|}
\hline Study & Subjects & $\begin{array}{l}\text { Age (mean or range; } \\
\text { years) }\end{array}$ & BP measurement method \\
\hline & $\begin{array}{l}\text { score of at least 20) with referrals to outpatient } \\
\text { clinics in geriatric medicine, old age psychiatry } \\
\text { and neurology and living in Norway }\end{array}$ & & $\begin{array}{l}\text { min of standing, BP was measured } \\
\text { using an analogue } \\
\text { sphygmomanometer }\end{array}$ \\
\hline $\begin{array}{l}\text { Wecht } \\
2016[33]\end{array}$ & $\begin{array}{l}\text { Male and female veterans attending an urban } \\
\text { Medical Centre, U.S.A }\end{array}$ & $21.0-88.0$ & $\begin{array}{l}\text { After } 10 \text { min supine rest and during } \\
10 \text { min of standing, BP was measured } \\
\text { in the right arm at } 1 \text { min intervals } \\
\text { using an automated } \\
\text { sphygmomanometer (Dynamap Pro } \\
\text { 300; GE Healthcare, Buckinghamshire, } \\
\text { UK) }\end{array}$ \\
\hline
\end{tabular}

\section{Not reported but fits consensus definition of $\mathrm{PH}$}

\section{Alli}

$1992[34]$

Atli

2006 [35]

2007 [10]

Hiorth

2019 [37]

Kamaruzzaman

2010 [38]

Liepelt Scarfone 2015 [39]

Liu $2016[40]$
Male and female participants aged over 65 years, attending general practices in Italy

Male and female participants aged over 65 years, attending the outpatient clinic of Ankara University School of Medicine, Department of Geriatric Medicine, Turkey

Bengtsson Lindberg 154 male and female dementia patients (50 with Alzheimer's disease, 54 with Alzheimer's disease with vascular components, 50 with dementia with Lewy bodies) attending a Memory Clinic and 50 controls, in Sweden

Male and female participants aged over 55 years, living in Portugal, attending primary healthcare centres in the community

Male and female participants, with incident, drug-naïve Parkinson's disease, residing in Southern and Western Norway

Females aged $60-80$ years of age, living in the U. K and attending general practices

Male and female patients with Parkinson's disease, aged over 50 years, attending the outpatient clinic of the Department of Neurodegeneration, University of Tübingen, Germany

Male and female participants attending a community health centre in Chengdu, China
Individuals living in Japan, aged $\geq 65$ years with normotension ( $\leq 140 / 90 \mathrm{mmHg}$ ) or established hypertension $(160 / 95 \mathrm{mmHg})$ treated with calcium channel blockers, beta blockers, alpha blockers, angiotensin converting enzyme inhibitors or diuretics after a 1 month placebo run-in period

Male and female patients, aged over 70 years, who visited a hospital in Japan for day care, programmed for those with dementia
BP was measured in the sitting position, after 5 min of supine rest and $30 \mathrm{~s}$ after standing up using a mercury sphygmomanometer

After 20 min of supine rest and $3 \mathrm{~min}$ after standing, BP was measured using a manual sphygmomanometer

After 10 min of supine rest, immediately after standing and at 1 , 3, 5 and 10 min of standing, BP was measured using a validated digital sphygmomanometer (Omron M5-1; Omron Healthcare Co. Kyoto, Japan)

After 5 and 7 min of seated rest, and at 2 and 5 min after standing, BP was measured using a calibrated mercury sphygmomanometer

BP was measured in a supine position and after 1 min of standing, using a manual sphygmomanometer

Two sitting BP measurements, followed by two standing measurements were recorded at 1 min intervals. The BP device was not stated

After 2 min supine rest and after 2 min of standing, BP was measured manually

After 5 min of seated rest, BP was measured in the right arm, twice (at 1 min apart) using a calibrated electronic device (Omron HEM-7200; Omron Healthcare Co. Kyoto, Japan). After 10 further min of supine rest, and at $30 \mathrm{~s}$ and 2 min after standing, $\mathrm{BP}$ was recorded again and these measurements were used to determine postural hypotension

BP was measured after 5 min of seated rest, $10 \mathrm{~min}$ supine rest and after standing for $2 \mathrm{~min}$ (in this order). The BP device was not stated electronic device (Parama-Tech PS501) in the supine position after a few minutes of rest and immediately on standing and at 1, 3 and 5 min after 
Table 2 Studies included in meta-analysis for consensus definition of postural hypotension (Continued)

\begin{tabular}{ll}
\hline Study & Subjects \\
\hline & \\
Perez Orcero & $\begin{array}{l}\text { Male and female patients, aged over } 80 \text { years, } \\
\text { able to stand for } 5 \text { or more minutes and } \\
\text { attending an urban primary health care centre } \\
\text { or treated at home by a family doctor or nurse } \\
\text { were included }\end{array}$
\end{tabular}

Van Hateren 2012 [44]

1991 [45]

Zhu

2016 [46]
Male and female patients, aged $\geq 70$ years, with type 2 diabetes attending general practices in the Netherlands

Male and female individuals, aged 63-93 years attending a day centre

Multiethnic Asian ambulatory male and female patients, aged $\geq 65$ years, attending a typical public primary care clinic located in the mideastern part of Singapore

\section{Age (mean or range; BP measurement method}

years)

\section{Community care}

\section{Reported as consensus definition of $\mathrm{PH}$}

Cremer 2017 [47]

Drozdz 2016 [48]

Foster-Dingley 2018 [49]

Hiitola 2009 [50]

Kartheek 2011 [51]

Mendez 2018 [52]
Male and female participants, aged over 65 years, living in three cities in France (Bordeaux, Dijon and Montpellier.)

Male and female participants, aged over 18 years, with New York Heart Association class II-II chronic heart failure, with left ventricular ejection fraction $<40 \%$ under stable conditions, with no cardiovascular interventions in the past 3 months and stable on pharmacological treatment in the 4 weeks prior to study enrolment

Male and female participants, aged at leas 75 years, using antihypertensive medication, with a systolic BP $160 \mathrm{mmHg}$ or less and a Mini Mental State examination score of 21-27. Participants were residing in the Netherlands and did not have serious cardiovascular disease or a clinical diagnosis of dementia

Male and female home-dwelling participants, aged over 75 years, living in Kuopio in Eastern Finland

Male and female participants, aged 20-90 years, of mixed socioeconomic status, living in Kurnool and Kadapa district urban areas of India. Participants were non-smokers and free of any cardiorespiratory disease

Male and female participants aged over 55 years, residing in Venezuela
After 5 min of supine rest and immediately on standing, BP was measured once using an automated oscillometric device (Omron CP750, Omron Healthcare Co. Kyoto, Japan)

After 10 min of supine rest and within 3 min of standing, BP was measured using a validated oscillometric device (Omron M6: Omron Healthcare Co. Kyoto, Japan)

After 5 min of seated rest, BP was measured twice (separated by 1-2 min) and within 3 min of standing, BP was measured 3 times, on the right arm. An automatic electronic sphygmomanometer (Omron M6 Forest, llinois, USA)

After 10 min of rest, BP was measured 34.0 in the supine, seated and standing positions (at 1 and $3 \mathrm{~min}$ ) by a trained nurse using a calibrated mercury column sphygmomanometer

BP was measured in the right arm using a mercury sphygmomanomete after 5 min of supine rest and at 1 and $3 \mathrm{~min}$ following standing. The average of two readings were taken to determine BP

$\mathrm{BP}$ was measured in the supine standing

After 5 min of rest in the supine position, 2 separate BP readings were taken 1 min apart, and then BP was measured immediately on standing and at 1, 3 and 5 min after standing, using a validated and calibrated oscillometric Omron 705-CP device (Omron Healthcare Co. Kyoto, Japan)

After 5 min of rest, two BP measurements were performed in the supine position and at 1 and $3 \mathrm{~min}$ following standing, using a validated A\&D digital monitor (UA-767 plus 30). The mean of the two measurements at each time point was calculated

After 20 min of supine rest and after 2 min of standing, BP was measured using a standard sphygmomanometer

After 5 min of supine rest, BP was measured 3 times in the right arm. In addition, BP was measured at 1 and 3 min following standing using a calibrated DINAMAP BP machine (Procare 100; GE Healthcare, Little Chalfont, Buckinghamshire, UK) comfort; Omron Healthcare, Inc., Lake

Prevalence of $\mathrm{PH}(\%)$ position and at 1 and 3 min after standing using the same oscillometric device (Dinamap 8100, Critikon Inc. Tampa, FL, USA) 
Table 2 Studies included in meta-analysis for consensus definition of postural hypotension (Continued)

\begin{tabular}{|c|c|c|c|c|}
\hline Study & Subjects & $\begin{array}{l}\text { Age (mean or range; } \\
\text { years) }\end{array}$ & BP measurement method & $\begin{array}{l}\text { Prevalence } \\
\text { of PH (\%) }\end{array}$ \\
\hline $\begin{array}{l}\text { Nguyen } \\
2017[53]\end{array}$ & $\begin{array}{l}\text { Male and female participants, aged } 60 \text { years or } \\
\text { older, able to communicate and sit and stand } \\
\text { in } 3 \text { min, residing in Ben Tre, a Southern Province } \\
\text { Vietnam }\end{array}$ & 70.4 & $\begin{array}{l}\text { After at least } 15 \text { min of rest, two } \\
\text { seated BP measurements were } \\
\text { obtained, separated by } 5 \text { min. The } \\
\text { mean of the two sitting BPs were } \\
\text { used for analysis. BP measurements } \\
\text { were repeated after standing for } 3 \\
\text { min. BP was measured using a } \\
\text { calibrated Omron electronic } \\
\text { sphygmomanometer (model HEM } \\
\text { 7130, OMRON Corp, Kyoto, Japan) }\end{array}$ & 14.9 \\
\hline $\begin{array}{l}\text { Putnam } \\
2018[54]\end{array}$ & $\begin{array}{l}\text { Male and female participants, aged } \\
70 \text { years or older, residing in Tanzania }\end{array}$ & $72-80$ & $\begin{array}{l}\text { BP was measured using a calibrated } \\
\text { A\&D Medical UA-1020 Digital BP } \\
\text { monitor in the supine position, } \\
\text { followed by } 30 \text { s, } 1,2 \text { and } 3 \text { min after } \\
\text { standing }\end{array}$ & 26.8 \\
\hline $\begin{array}{l}\text { Rockwood } \\
2012[55]\end{array}$ & $\begin{array}{l}\text { Elderly male and female participants living } \\
\text { in Canada }\end{array}$ & 83.2 & $\begin{array}{l}\text { BP was measured in supine and } \\
\text { standing positions (or seated in those } \\
\text { unable to stand) within } 3 \mathrm{~min} \text { using a } \\
\text { sphygmomanometer }\end{array}$ & 17.7 \\
\hline $\begin{array}{l}\text { Veronese } \\
2014[56]\end{array}$ & $\begin{array}{l}\text { Male and female participants, aged } \\
\geq 65 \text { years, living in Italy }\end{array}$ & 73.8 & $\begin{array}{l}\text { BP was measured } 3 \text { times in the right } \\
\text { arm, with } 30 \text { s between each } \\
\text { measurement, using a mercury } \\
\text { sphygmomanometer (Erkameter } 300 \text { ) } \\
\text { with subjects in a supine position. BP } \\
\text { measurements were also recorded at } \\
1 \text { and } 3 \text { min after standing }\end{array}$ & 32.2 \\
\hline $\begin{array}{l}\text { Wolters } \\
2016[57]\end{array}$ & $\begin{array}{l}\text { Male and female participants, aged } \geq 55 \text { years, } \\
\text { from the Ommoord area, a suburb of Rotterdam, } \\
\text { Netherlands }\end{array}$ & 68.5 & $\begin{array}{l}\text { After } 5 \text { min of supine rest, the mean } \\
\text { of } 2 \text { BP measurements were recorded. } \\
\text { BP was also recorded following } 1,2 \\
\text { and } 3 \text { min of standing using an } \\
\text { automatic machine (Dinamap, } \\
\text { Critikon) }\end{array}$ & 12.5 \\
\hline
\end{tabular}

\section{Not reported but fits consensus definition of $\mathrm{PH}$}

Assantachai Male and female participants, aged over 60 years, 1998 [58] $\quad$ living in Bangkok and able to perform postural change from lying to standing by themselves

Cilia
Male and female patients with Parkinson's disease for $\geq 20$ years

Male and female participants, aged over 65 years, independent in ambulation and attending a primary care clinic in Israel
After 10 min of supine rest, BP was measured twice using a digital sphygmomanometer. BP was then recorded twice during $1-2$ min of standing,

After 20 min of supine rest, BP was measured every $30 \mathrm{~s}$ for 2 min (2-5 measurements, $90 \%$ of participants had $\geq 4$ measurements) using a Dinamap 1846 SX automated oscillometric device. BP was then measured repeatedly for the first 2 min after standing (2-5 measurements, $91 \%$ of participants had $\geq 4$ measurements)

After at least 20 min of supine rest and after 3 min of standing, BP was measured using a mercury sphygmomanometer (Baumanometer W.A. Baum, Copiague, NY)

BP protocol or device not reported

$\mathrm{BP}$ was measured every min during 10 min of supine rest and within 1 min of standing and repeated at 1 min intervals another 6 times. BP was measured using an automatic Scholar III 507 EL monitor (CSI - Criticare Systems, Inc.)

After at least 5 min of supine rest, BP was measured 3 times in the right arm, at 30 s intervals, using a mercury 
Table 2 Studies included in meta-analysis for consensus definition of postural hypotension (Continued)

\begin{tabular}{|c|c|c|}
\hline Study & Subjects & $\begin{array}{l}\text { Age (mea } \\
\text { years) }\end{array}$ \\
\hline $\begin{array}{l}\text { Ensrud } \\
1992[62]\end{array}$ & $\begin{array}{l}\text { Female participants, aged over } 65 \text { years, residing } \\
\text { in the U.S.A: Portland, Minneapolis, Baltimore } \\
\text { and Monongahela Valley, near Pittsburgh }\end{array}$ & 71.7 \\
\hline $\begin{array}{l}\text { Fan } \\
2010[63]\end{array}$ & $\begin{array}{l}\text { Male and female rural community residents, aged } \\
40-75 \text { years, living in Xinyang County, China }\end{array}$ & $40.0-75.0$ \\
\hline $\begin{array}{l}\text { Fedorowski } 2010 \\
\text { [64] }\end{array}$ & $\begin{array}{l}\text { Middle-aged male and female individuals, living } \\
\text { in Sweden }\end{array}$ & 45.7 \\
\hline $\begin{array}{l}\text { Frewen } \\
2014[65]\end{array}$ & $\begin{array}{l}\text { Community-dwelling male and female individuals, } \\
\text { aged over } 50 \text { years, living in the Republic of Ireland }\end{array}$ & 63 \\
\hline
\end{tabular}

$\begin{array}{ll}\text { Gangavati } & \text { Male and female individuals, aged over } \\ 2011[66] & 70 \text { years, who were able to understand and } \\ & \text { communicate in English, walk } 20 \mathrm{ft} \text {. without } \\ & \text { assistance and living in Boston, U.S.A }\end{array}$

Luukkonen 2017 Male and female home care clients, aged over
Lampela

2013 [67]

Luukinen

1999 [68]

[69]

75 years, living in Eastern and Central Finland

Male and female participants, aged $\geq 75$ years, living in Kuopio, Finland, including mainly home-dwelling individuals, but part of the sample were living in institutional care

Male and female home-dwelling participants, aged over 70 years, living in 5 rural municipalities in northern Finland

Mader

1987 [70]

Masaki

1998 [71]

O'Connell

2015 [72]
Independent, community living individuals, aged over 55 years who utilise the free health screening services of Santa Monica Senior Health and Peer Counseling Center, U.S.A

Males of Japanese ancestry, aged 45-68 years and living on the island of Oahu, Hawaii

Community-dwelling male and female individuals, aged over 50 years, living in the Republic of Ireland
Prevalence of $\mathrm{PH}(\%)$

sphygmomanometer (Erkameter 300). $\mathrm{BP}$ was then measured after 1 and 3 min of standing

After 5 min of supine rest and after 1 min of assuming a standing position, $\mathrm{BP}$ was measured in the right arm using a Baum mercury sphygmomanometer

After 15 min of supine rest, BP was measured 3 times in the right arm at $30 \mathrm{~s}$ intervals and at $30 \mathrm{~s}$ and $2 \mathrm{~min}$ after standing

After 10 min of supine rest and at 1 min after standing up, BP was measured using a mercury sphygmomanometer

After 30 min of seated rest, 2 BP measurements were recorded, separated by 1 min, using an automatic digital BP monitor (Omron M10-IT; Omron Healthcare Co. Kyoto, Japan). After 1 min of standing, a single BP measurement was also recorded

After 5 min of supine rest, 2 BP measurements were recorded, separated by $1 \mathrm{~min}$, using a standard sphygmomanometer. The mean of the 2 measurements were used for analysis. BP was also recorded at 1 and 3 min after standing

BP was measured after 10 min of rest in the supine position, 1 min after sitting and after 1 and 3 min of standing using an electronic sphygmomanometer or mercury where needed (e.g. if atrial fibrillation was present)

After 5 min of supine rest and at 1 and 3 min after standing up, BP was measured in the right arm using a mercury manometer

After 10 min of supine rest, the first BP was measured. The second BP was measured in the seated position, followed further BP measurements at 1 and 3 min after standing using an automated BP device

After 5 min of supine rest, 3 BP measurements were recorded over a 5 min period using a mercury manometer (Baumanometer). The mean of the second and third BP measurements were used. BP was also measured 1 min after standing

After at least 15 min of supine rest and after 3 min of standing, BP was measured using a standard mercury sphygmomanometer

After at least 30 min of seated rest, 2 $\mathrm{BP}$ measurements were recorded and the mean was used for analysis. A single BP measurement was also recorded after 1 min of standing using an automated BP device (Omron 
Table 2 Studies included in meta-analysis for consensus definition of postural hypotension (Continued)

\begin{tabular}{|c|c|c|c|c|}
\hline Study & Subjects & $\begin{array}{l}\text { Age (mean or range; } \\
\text { years) }\end{array}$ & BP measurement method & $\begin{array}{l}\text { Prevalence } \\
\text { of } \mathrm{PH}(\%)\end{array}$ \\
\hline & & & $\begin{array}{l}\text { M10-IT; Omron Healthcare Co. Kyoto, } \\
\text { Japan) }\end{array}$ & \\
\hline $\begin{array}{l}\text { Ong } \\
2017 \text { [73] }\end{array}$ & $\begin{array}{l}\text { Male and female individuals, aged over } 60 \text { years, } \\
\text { living in the community (day care centres, nursing } \\
\text { homes and institutions were included) who were } \\
\text { citizens or permanent residents in Singapore }\end{array}$ & $>60.0$ & $\begin{array}{l}\text { Two sitting BP measurements were } \\
\text { recorded and the mean was used for } \\
\text { analysis. Standing BP was also } \\
\text { measured after } 2 \text { min using a standard } \\
\text { electronic sphygmomanometer } \\
\text { (Omron HEM- } 7211 \text {; Omron Healthcare } \\
\text { Co. Kyoto, Japan) }\end{array}$ & 7.8 \\
\hline $\begin{array}{l}\text { Shin } \\
2004[74]\end{array}$ & $\begin{array}{l}\text { Male and female Korean individuals, aged } \\
40-69 \text { years, living in an industrialised community } \\
32 \mathrm{~km} \text { southwest of Seoul, South Korea (Ansan) } \\
\text { and in a rural setting, } 100 \mathrm{~km} \text { south of Seoul (Ansung) }\end{array}$ & $40.0-69.0$ & $\begin{array}{l}\text { After at least } 5 \text { min of supine rest, BP } \\
\text { was measured } 3 \text { times at } 30 \mathrm{~s} \text { intervals } \\
\text { and the mean was used for analysis. } \\
\text { Standing BP measurements were } \\
\text { recorded at } 0 \text { and } 2 \text { min after } \\
\text { standing }\end{array}$ & 13.9 \\
\hline $\begin{array}{l}\text { Vanhanen } \\
1996[75]\end{array}$ & $\begin{array}{l}\text { Male and female individuals, aged over } 60 \text { years, } \\
\text { with isolated systolic hypertension (sitting SBP } \\
160-219 \mathrm{mmHg} \text {, DBP }<95 \mathrm{mmHg} \text { and a standing } \\
\text { SBP } \geq 140 \mathrm{mmHg} \text { ) }\end{array}$ & 70.0 & $\begin{array}{l}\text { BP was measured twice after } 2 \text { min of } \\
\text { rest in the supine position, twice after } \\
5 \text { min of rest in the seated position } \\
\text { and twice after } 2 \text { min in the standing } \\
\text { position using conventional } \\
\text { sphygmomanometry }\end{array}$ & 15.0 \\
\hline $\begin{array}{l}\text { Velilla Zancada } \\
2017[76]\end{array}$ & $\begin{array}{l}\text { Male and female individuals, aged over } 18 \text { years, } \\
\text { living in Cantabria, Spain }\end{array}$ & 48.5 & $\begin{array}{l}\text { After } 5 \text { min of rest, } 3 \text { BP } \\
\text { measurements in the dominant arm } \\
\text { were recorded in the sitting position } \\
\text { using the validated and } \\
\text { semiautomatic device (Omron } 705 \text { CP; } \\
\text { Peróxidos Farmacéuticos S.A. } \\
\text { Barcelona, Spain) and the mean of the } \\
\text { final } 2 \text { measurements were used for } \\
\text { analysis. BP was also measured at } 1 \\
\text { and } 3 \text { min after standing }\end{array}$ & 7.4 \\
\hline $\begin{array}{l}\text { Viramo } \\
1999[77]\end{array}$ & $\begin{array}{l}\text { Male and female, home-dwelling and } \\
\text { institutionalised individuals, born in } 1920 \text { or earlier } \\
\text { and living in } 5 \text { rural municipalities around the } \\
\text { town of Oulu, Northern Finland }\end{array}$ & $>70.0$ & $\begin{array}{l}\text { After } 5 \text { min of supine rest and at } 1 \\
\text { and } 3 \text { min after standing, BP was } \\
\text { measured in the right arm. The BP } \\
\text { device was not stated }\end{array}$ & 28.7 \\
\hline $\begin{array}{l}\text { Wu } \\
2009[78]\end{array}$ & $\begin{array}{l}\text { Male and female community-dwelling individuals, } \\
\text { with normal glucose tolerance, pre-diabetes and } \\
\text { diabetes, aged } \geq 20 \text { years, living in Tainan, a city } \\
\text { in southern Taiwan }\end{array}$ & $\geq 20.0$ & $\begin{array}{l}\text { Two seated BP measurements were } \\
\text { recorded, with at least } 5 \text { min intervals, } \\
\text { after at least } 15 \text { min rest using a DINA } \\
\text { MAP vital sign monitor (model } \\
18465 X ; \text { Critikon, Irvine, CA). BP was } \\
\text { also measured twice in the supine } \\
\text { position followed by measurements at } \\
1 \text { and } 3 \text { min after standing }\end{array}$ & 15.9 \\
\hline $\begin{array}{l}\text { Yap } \\
2008 \text { [79] }\end{array}$ & $\begin{array}{l}\text { Male and female individuals, aged over } \\
55 \text { years, living in the south-east region of } \\
\text { Singapore }\end{array}$ & 65.5 & $\begin{array}{l}\text { After at least } 10 \text { min of rest, BP was } \\
\text { measured up to } 3 \text { times, at } 30 \mathrm{~s} \\
\text { intervals, in the right arm in the } \\
\text { supine, seated and standing positions } \\
\text { using a standard mercury } \\
\text { sphygmomanometer. The mean of } \\
\text { the two closest readings was used for } \\
\text { analysis }\end{array}$ & 16.6 \\
\hline
\end{tabular}

score of 8; range: 3-10) were notable in categories relating to the response rates of participants and in comparability between respondents and non-respondents (usually due to lack of information provided), and the use of non-validated methods for BP measurement (Table 3.).

\section{Reported prevalences}

Overall, $\mathrm{PH}$ prevalence using the consensus definition was $18 \%$ (95\% confidence interval, $\left.16-21 \%, \mathrm{I}^{2}=99 \%\right)$. Pooled prevalences of $\mathrm{PH}$ were $17 \%\left(14-20 \%\right.$; $\left.\mathrm{I}^{2}=99 \%\right)$ for 34 community cohorts, $19 \%\left(15-25 \%\right.$; $\left.\mathrm{I}^{2}=98 \%\right)$ for 23 primary care cohorts and $31 \%\left(15-50 \% ; \mathrm{I}^{2}=0 \%\right)$ for three nursing/ residential care home cohorts $(P=0.16$ for between group differences, see Fig. 2). When low quality studies were omitted from analyses, pooled prevalences of PH were $18 \%$ $\left(15-23 \% ; \mathrm{I}^{2}=99 \%\right)$ for 20 community cohorts, $22 \%$ $\left(18-26 \%\right.$; $\left.\mathrm{I}^{2}=93 \%\right)$ for 10 primary care cohorts and $20 \%$ (17-22\%; $\left.\mathrm{I}^{2}=0 \%\right)$ for two nursing/residential care home cohorts $(P=0.38$ for between group differences). 


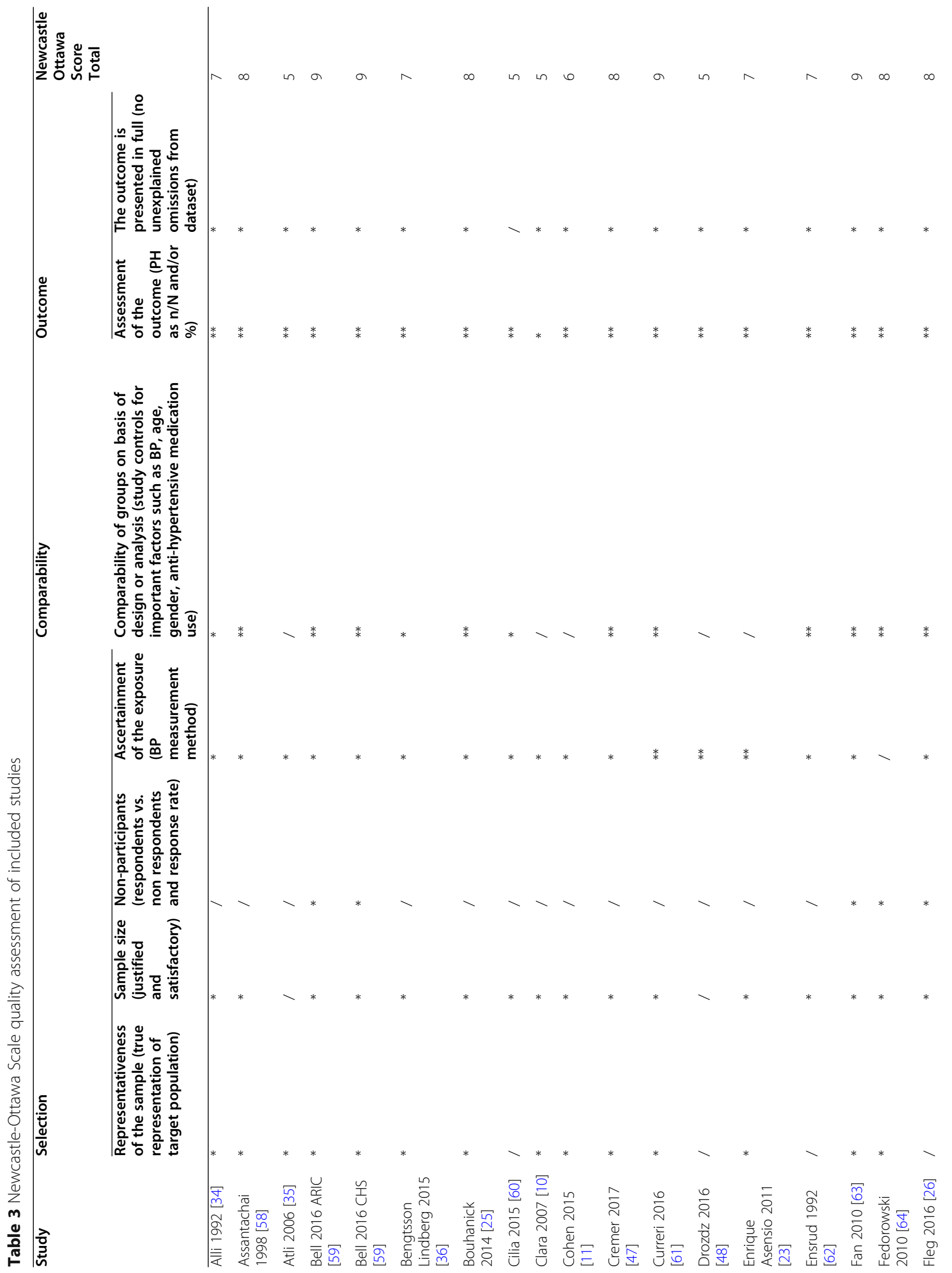




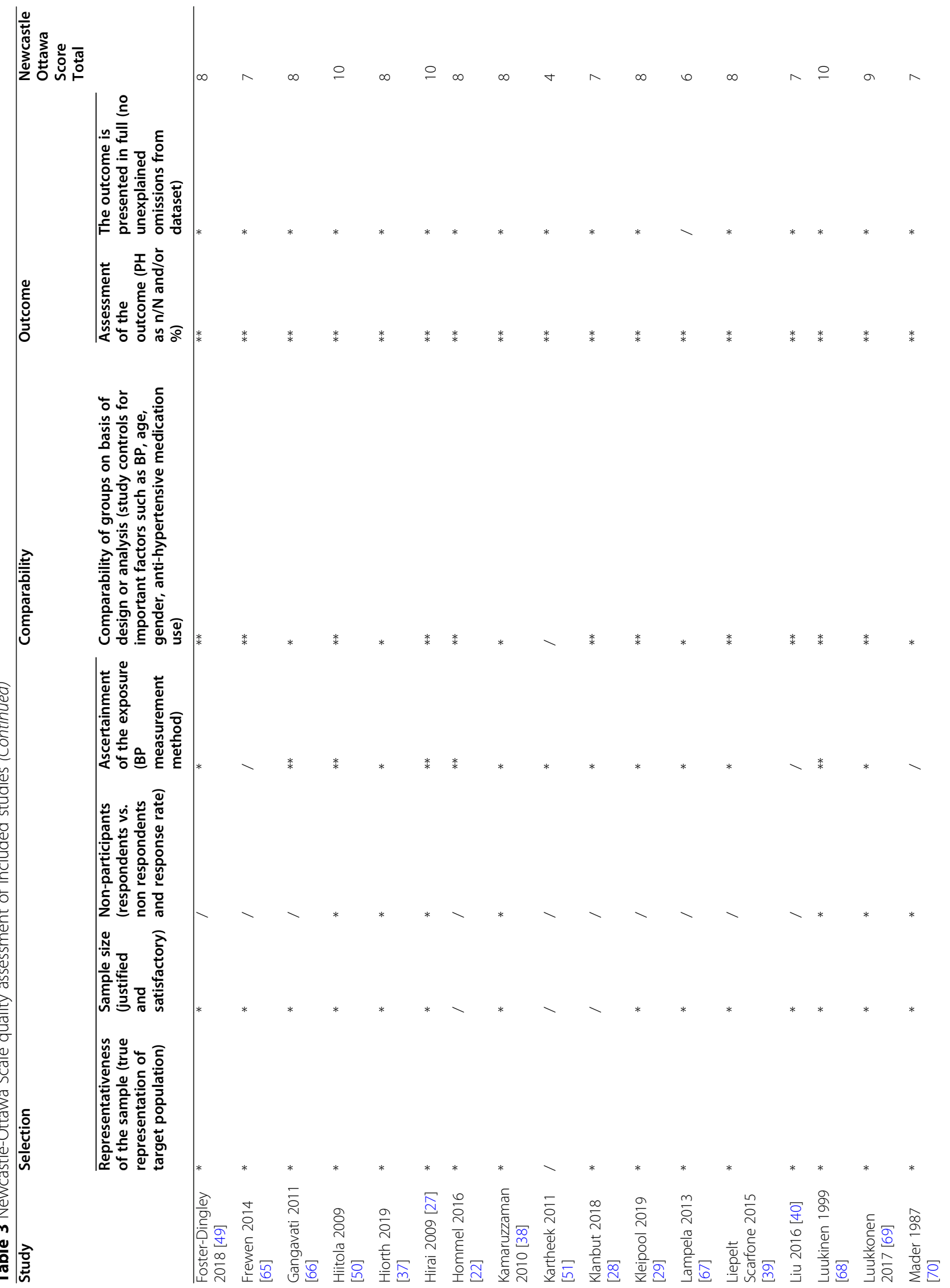




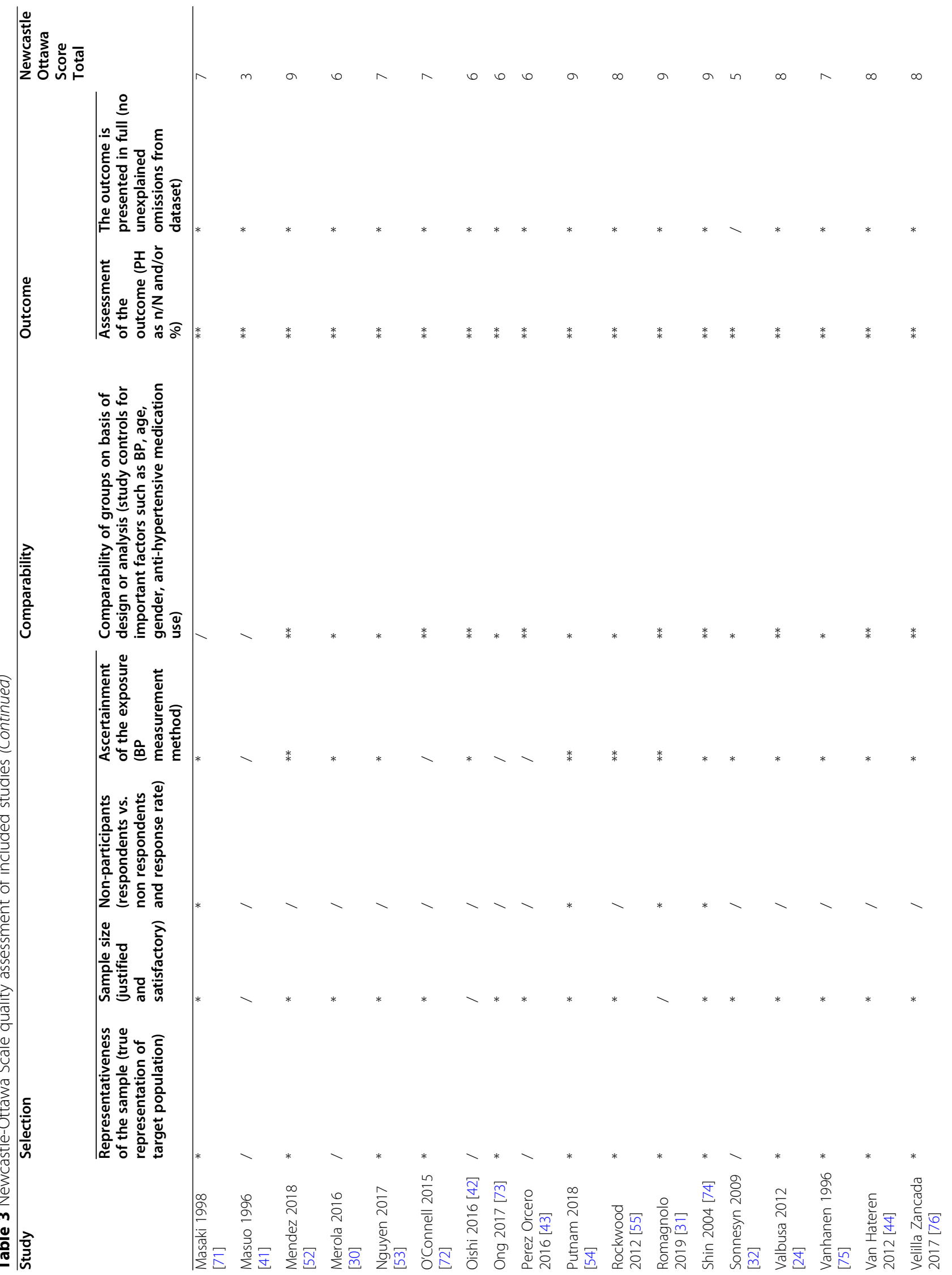




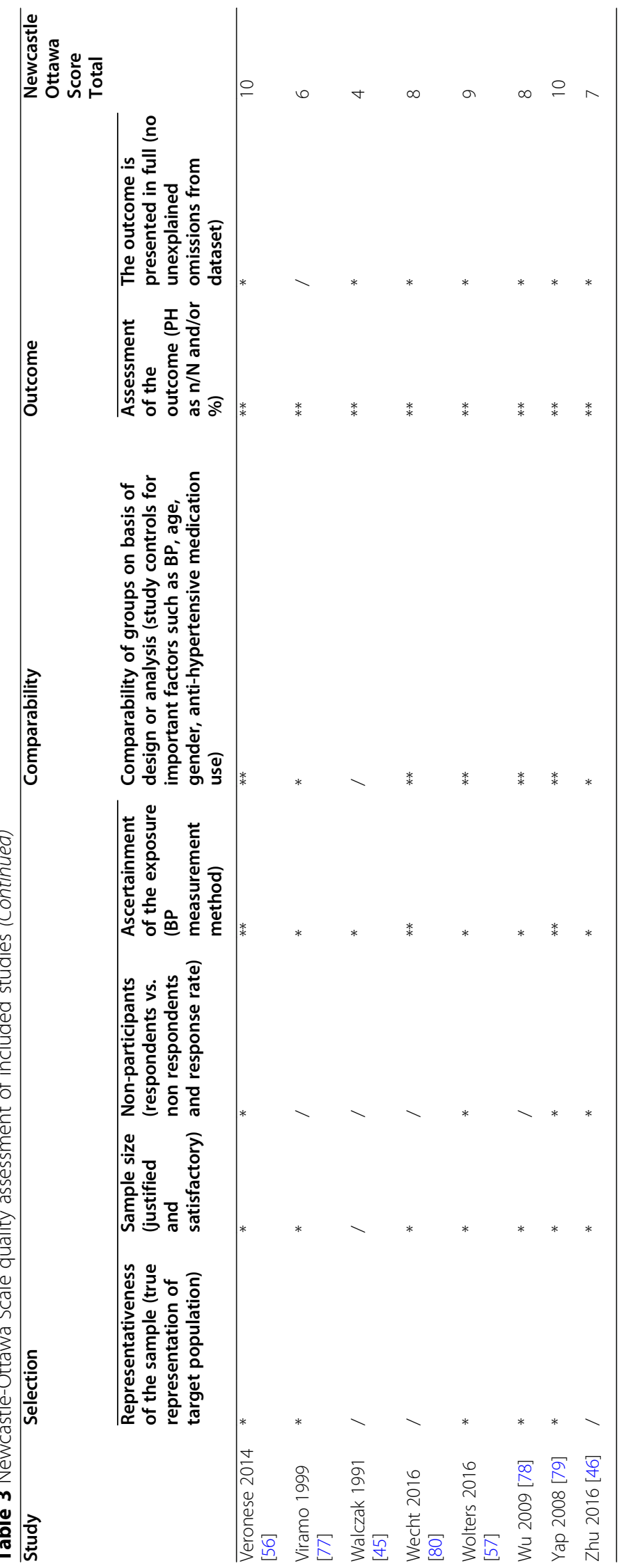




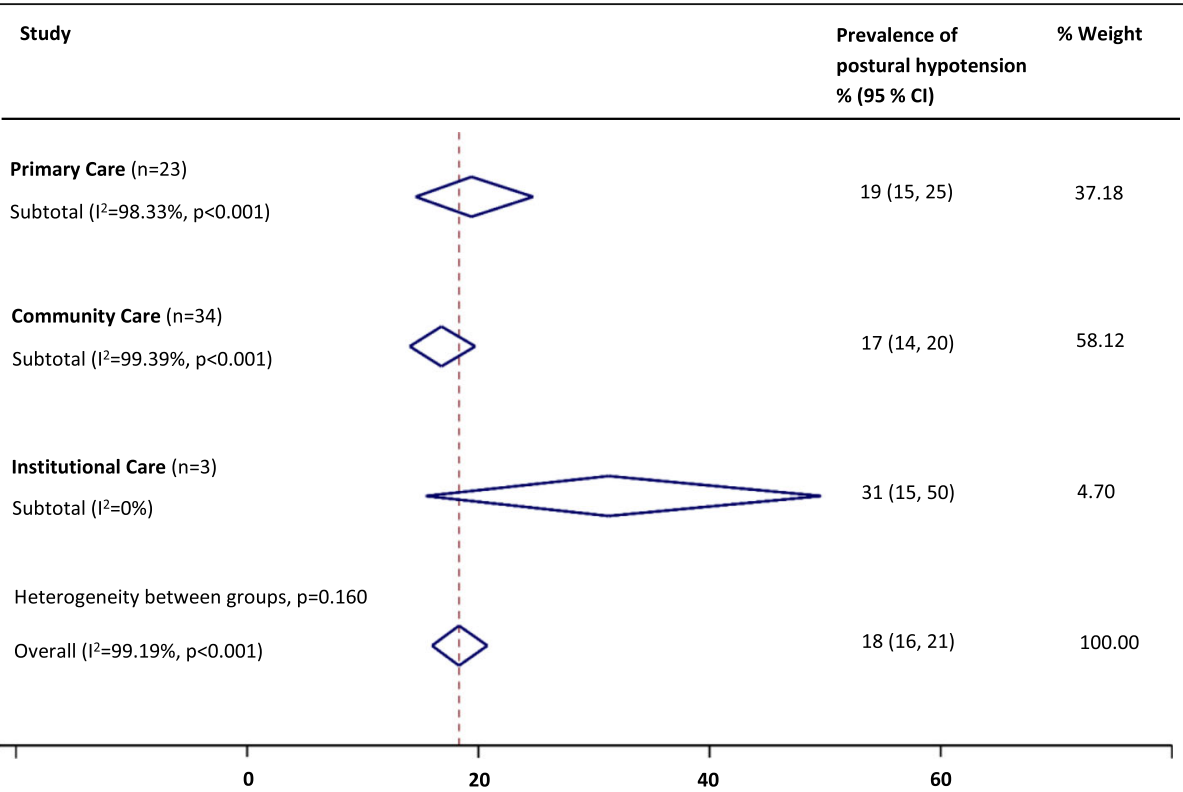

Fig. 2 Summary of the prevalence of postural hypotension according to the consensus definition across care settings

For disease subgroups, pooled prevalences of $\mathrm{PH}$ were $19 \%\left(16-23 \% ; \mathrm{I}^{2}=98 \%\right)$ in hypertension (20 cohorts), $21 \%\left(16-26 \% ; \mathrm{I}^{2}=92 \%\right)$ in diabetes (four cohorts), $25 \%$ $\left(18-33 \% ; \mathrm{I}^{2}=88 \%\right)$ in Parkinson's disease (seven cohorts) and 29\% $\left(25-33 \% ; \mathrm{I}^{2}=0 \%\right)$ in dementia (three cohorts), compared with $14 \%\left(12-17 \% ; I^{2}=99 \%\right)$ for those without these conditions ( 26 cohorts; $P<0.01$ for between group differences; Fig. 3.). When low quality studies were omitted from analyses, pooled prevalences of $\mathrm{PH}$ were $21 \%\left(17-26 \% ; \mathrm{I}^{2}=98 \%\right)$ in hypertension (10 cohorts), $21 \%\left(16-26 \%\right.$; $\left.\mathrm{I}^{2}=92 \%\right)$ in diabetes (four cohorts), 29\% (16-44\%; $\left.\mathrm{I}^{2}=91 \%\right)$ in Parkinson's disease (four cohorts) and 29\% (27-31\%; $\left.\mathrm{I}^{2}=0 \%\right)$ in dementia (one cohort), compared with $17 \%\left(13-21 \%\right.$; $\left.\mathrm{I}^{2}=99 \%\right)$ for those without these conditions (13 cohorts; $P<0.01$ for between group differences).

Where the consensus definition of $\mathrm{PH}$ was reported at study level, prevalence estimates were higher (23\%; 19-27\%) than those definitions of $\mathrm{PH}$ that were not reported as the consensus definition, but fell within the scope of the definition at study level $(16 \%$; $14-$ $19 \% ; P=0.01)$; this finding persisted on exclusion of low quality studies $(P=0.04)$. Sensitivity analyses revealed that the overall $\mathrm{PH}$ prevalence was not significantly affected by the type of BP measurement device [auscultatory, $17 \%(13-21 \%)$ or oscillometric, $18 \%$ (15-21\%); $P=0.65$, see Fig. 4.], or when measured from a seated $(15 \%$; $9-22 \%)$ rather than supine $(19 \%$; $16-22 \%)$ resting position $(P=0.24$, see Fig. 5.). When low quality studies were omitted, there remained no difference in $\mathrm{PH}$ prevalence between seated (22\%; $13-$ $34 \%)$ and supine $(20 ; 16-24 \%)$ BP measurement methods $(P=0.67)$. Heterogeneity remained high across all subgroups (e.g. setting, disease, PH definition and measurement method) and was not explained by the sensitivity analyses according to study quality. Egger tests $(P<0.01)$ and visual inspection of funnel plots suggested possible publication bias against low prevalence small studies (Fig. 6).

Univariable meta-regression showed three study level factors to be associated with mean prevalence of $\mathrm{PH}$ : age $(P<0.01)$, history of falls and disease status (all $P<0.05$, see Table 4). For multivariable analysis, age (Fig. 7.) and presence of diabetes remained as predictors of $\mathrm{PH}$ $\left(P<0.01, P=0.13\right.$, respectively; $\left.\mathrm{R}^{2}=36 \%\right)$.

\section{Discussiones}

\section{Summary}

This is, to our knowledge, the first systematic review and meta-analysis to present estimates of $\mathrm{PH}$ prevalence in populations regularly encountered in primary care, including general practices and related outpatient clinics, care or nursing homes and community settings. Our findings confirm that $\mathrm{PH}$, when tested for, is a common finding across care settings and disease subgroups, with the highest prevalences observed in people residing in care/nursing homes (and primary care, when low quality studies were omitted from analyses), and in those with dementia; age itself appears to be the key predictor of prevalence. The definition of $\mathrm{PH}$ used can impact prevalence estimates and therefore must be considered carefully in clinical practice. The type of $\mathrm{BP}$ measurement device and 


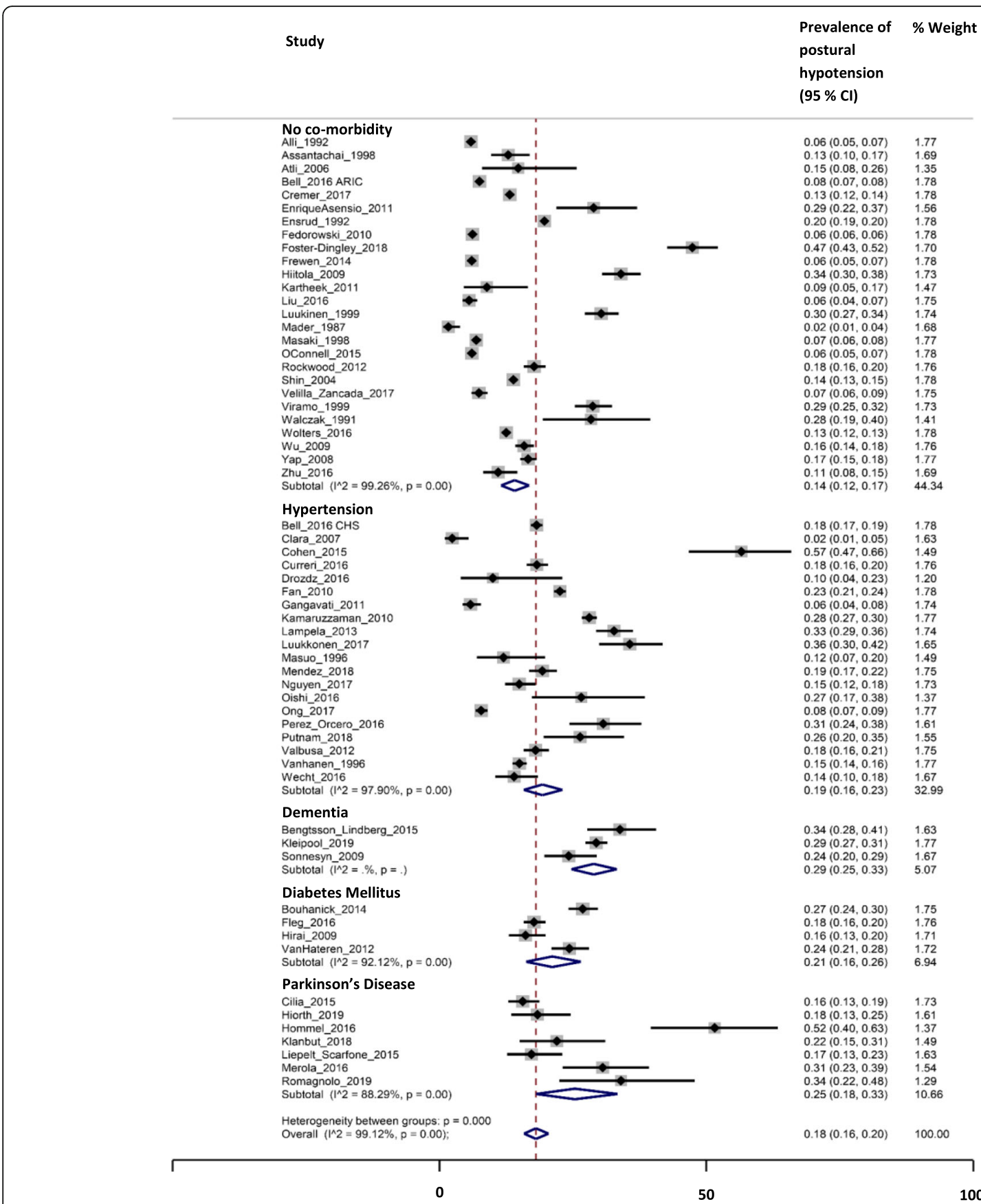

Fig. 3 Prevalence of postural hypotension according to the consensus definition across disease subgroups. 'Control' group represents those individuals with no co-morbidity

resting position does not appear to systematically impact $\mathrm{PH}$ prevalence estimates.

\section{Strengths and limitations}

This study provides insight into $\mathrm{PH}$ prevalences across a variety of care settings and disease cohorts. Our search terms were intentionally broad, thus it is unlikely that substantial numbers of relevant publications were overlooked. Data extraction was limited to English language papers and published records, although non English language and Grey literature data generally have been shown to make limited impact on review findings where a substantial body of published evidence exists [81]. We found some evidence for publication bias against low prevalence small studies; overall, there was considerable heterogeneity of $\mathrm{PH}$ prevalence estimates across 


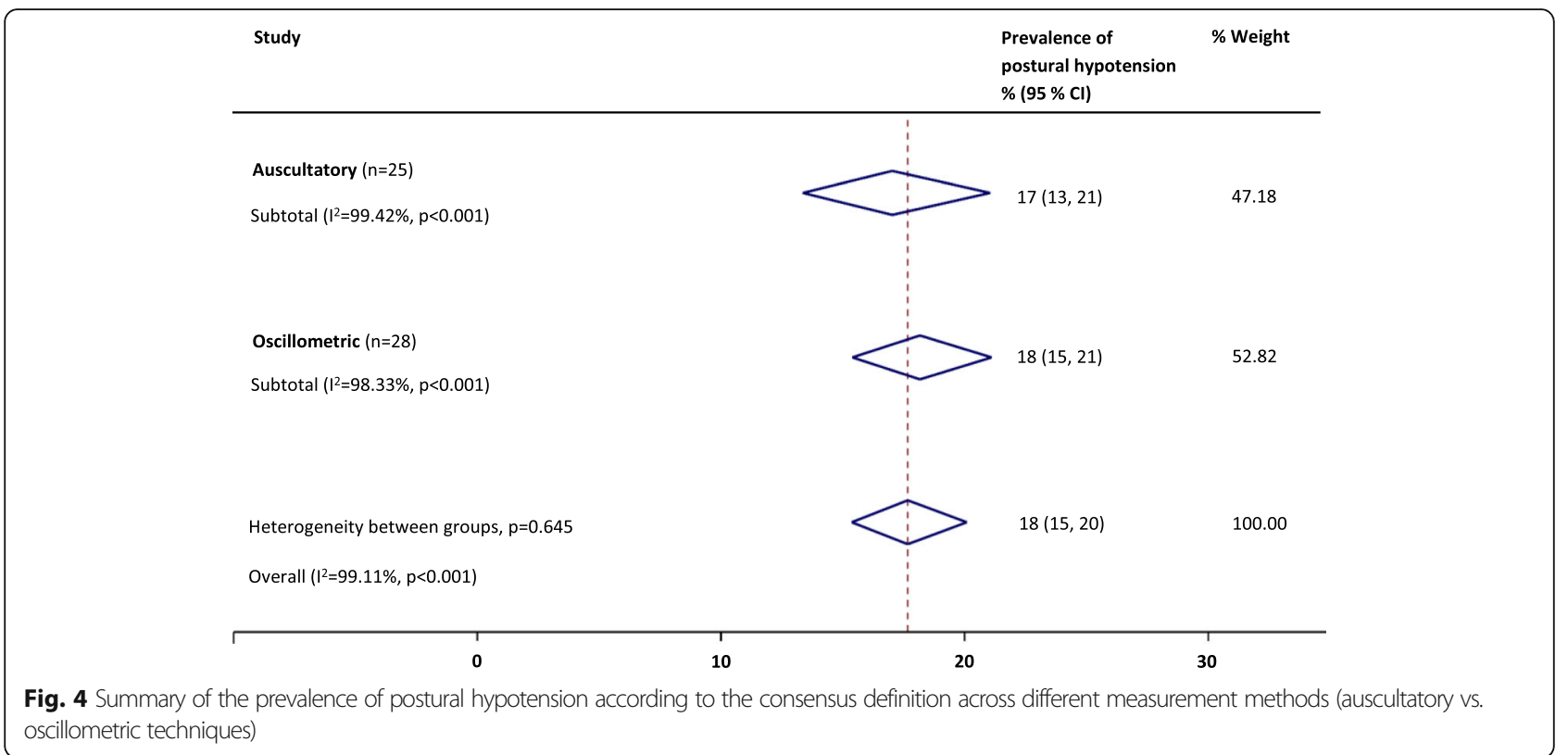

different care settings, disease cohorts, $\mathrm{PH}$ definitions and BP measurement methods that was not accounted for in our sensitivity analyses. The utility of the NOS for assessing study quality has previously shown poor agreement between reviewers, with calls for more specific guidance in its use [82]. We adapted the generic guidance to give context specific to this PH review (Appendix 2), however, we did not find any substantial impact on heterogeneity in subgroup analyses according to quality assessment of studies. High residual levels of heterogeneity limit our ability to draw firm conclusions from the data. $\mathrm{PH}$ prevalence varied widely across studies $(2.0-56.8 \%)$ and residual heterogeneity probably reflects cumulative effects of nonsystematic variations in population size and health status, limitations in classifying cohorts by condition at study level, and the discrepancy in PH definitions and measurement methods employed across studies.

Our univariable meta-regression showed that the presence of disease was associated with increasing $\mathrm{PH}$ prevalence, according to condition. This association did not persist when multivariable regression was undertaken, but there was co-linearity of disease status with diabetes, which was included a priori in the multivariable model. Increasing BP per se, a known risk factor for orthostatic

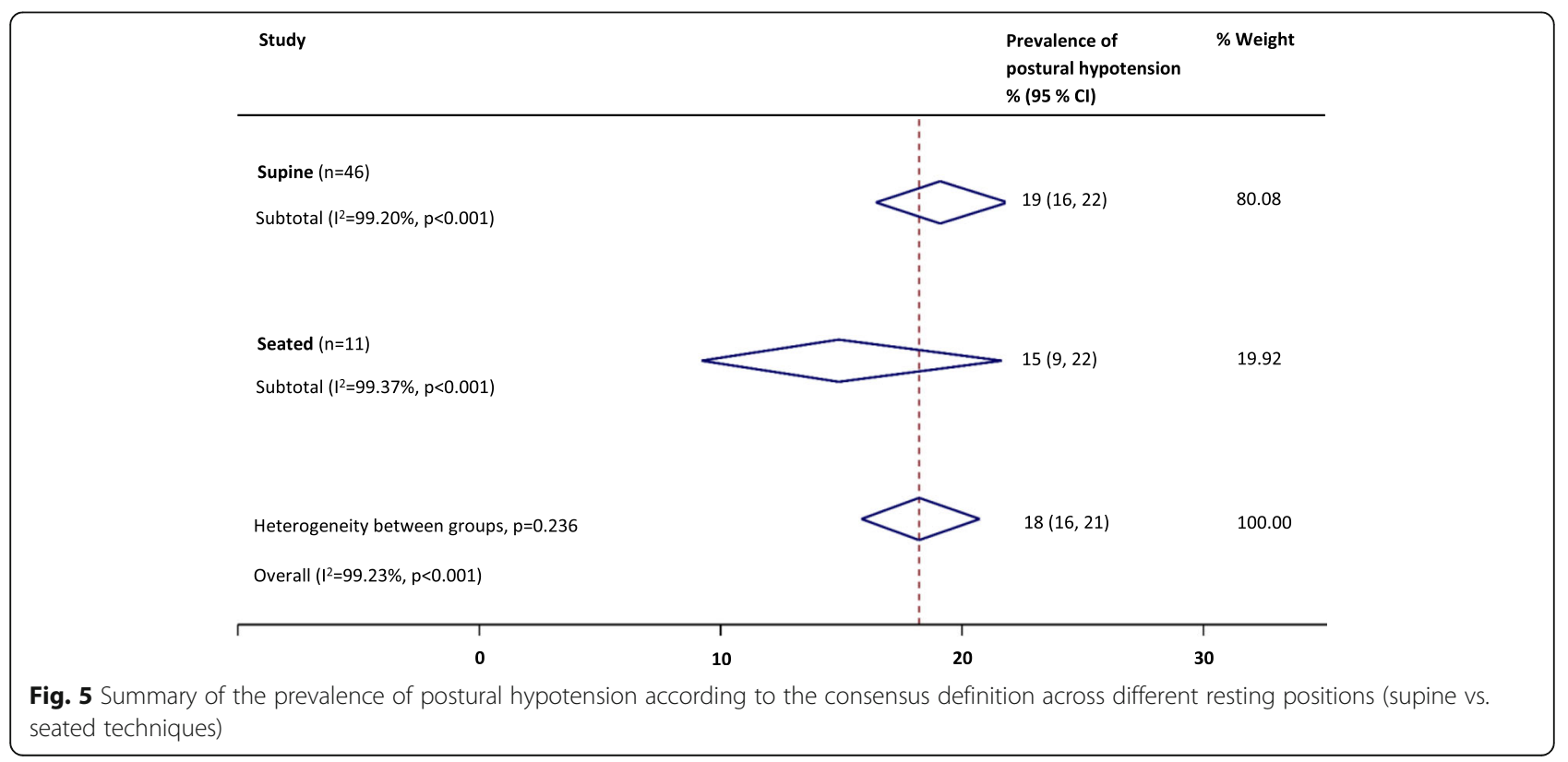




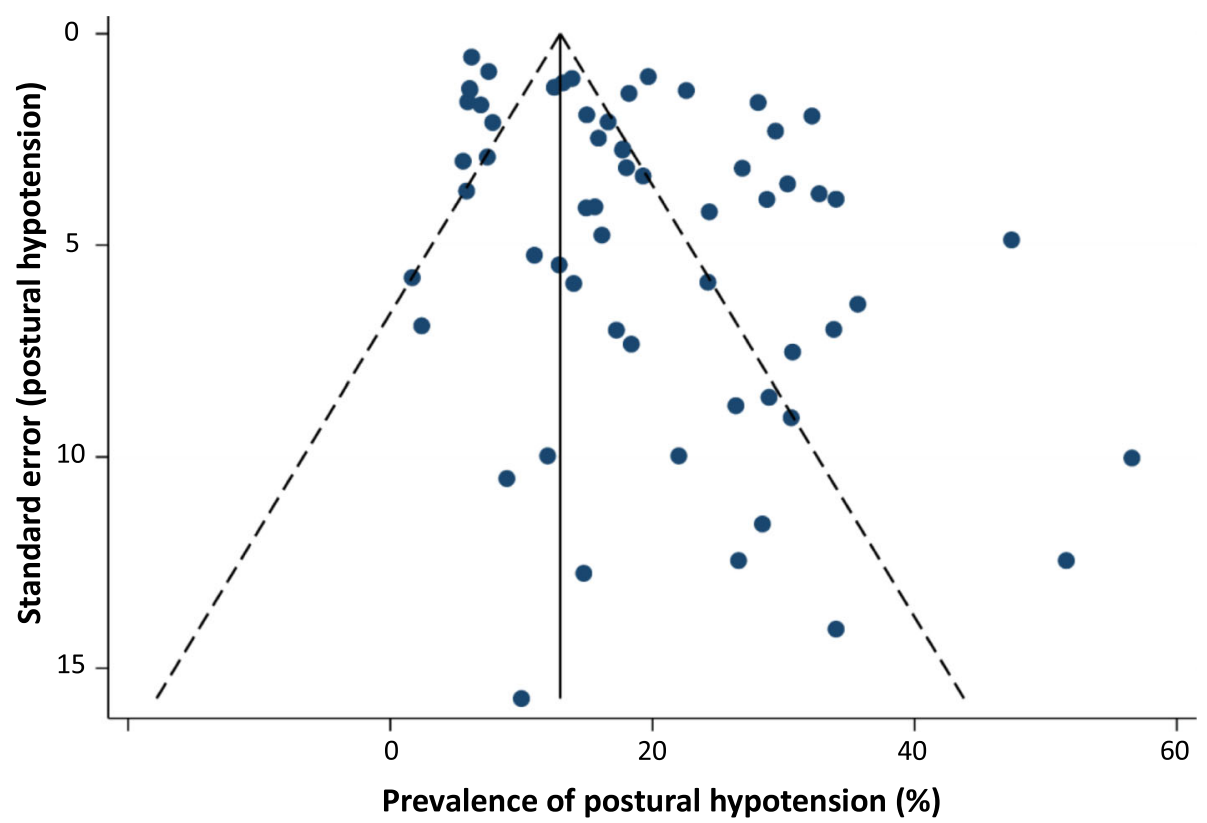

Fig. 6 Funnel plot for prevalence of postural hypotension (defined as a drop in systolic blood pressure of $\geq 20 \mathrm{mmHg}$ or diastolic blood pressure of $\geq 10 \mathrm{mmHg}$ within three minutes of rising to a standing position). Egger test $(P<0.01)$

hypotension [83], was not associated with increasing $\mathrm{PH}$ incidence; however, data for baseline BP were, surprisingly, only reported in 13 studies, limiting our ability to explore this association. The relationship of $\mathrm{PH}$ with hypertension is complex; $\mathrm{PH}$ is associated with both uncontrolled hypertension and the number of antihypertensive drugs used in managing high BP $[25,38$, $84,85]$, but effective treatment of high BP in elderly persons is associated with reduced $\mathrm{PH}$ prevalence $[41,86]$. Consequently, a non-linear or ' $U$ ' shaped relationship of prevalence to absolute BP might be expected, with interaction in analyses between a diagnosis of hypertension

Table 4 Univariable regression-analyses

\begin{tabular}{|c|c|c|c|c|}
\hline Variable & $P$-value & $95 \% \mathrm{Cl}$ & Coefficient & Studies reporting variable $(\mathrm{n})$ \\
\hline Age & $P=0.001$ & 0.002 to 0.009 & 0.0057 & 38 \\
\hline Gender & $P=0.086$ & -0.000 to 0.004 & 0.0016 & 55 \\
\hline Diabetes & $P=0.434$ & -0.000 to 0.002 & 0.0005 & 42 \\
\hline Hypertension & $P=0.153$ & -0.000 to 0.002 & 0.0009 & 49 \\
\hline BMI & $P=0.863$ & -0.032 to 0.038 & 0.0028 & 13 \\
\hline Coronary heart disease & $P=0.161$ & -0.003 to 0.014 & 0.0057 & 8 \\
\hline Stroke & $P=0.336$ & -0.005 to 0.014 & 0.0045 & 21 \\
\hline Parkinson's & $P=0.993$ & -0.001 to 0.001 & 0.0000 & 19 \\
\hline Falls & $P=0.025$ & 0.001 to 0.014 & 0.0073 & 12 \\
\hline Setting & $P=0.437$ & -0.187 to 0.043 & 0.0121 & 60 \\
\hline Disease status & $P=0.033$ & 0.002 to 0.381 & 0.0198 & 60 \\
\hline Blood pressure position & $P=0.470$ & -0.043 to 0.091 & 0.0243 & 58 \\
\hline Blood pressure device & $P=0.869$ & -0.059 to 0.069 & 0.0053 & 53 \\
\hline Seated systolic blood pressure & $P=0.797$ & -0.008 to 0.009 & 0.0009 & 7 \\
\hline Seated diastolic blood pressure & $P=0.530$ & -0.039 to 0.227 & 0.0008 & 7 \\
\hline Supine systolic blood pressure & $P=0.129$ & -0.003 to 0.165 & 0.0067 & 6 \\
\hline Supine diastolic blood pressure & $P=0.265$ & -0.189 to 0.052 & 0.0165 & 6 \\
\hline
\end{tabular}




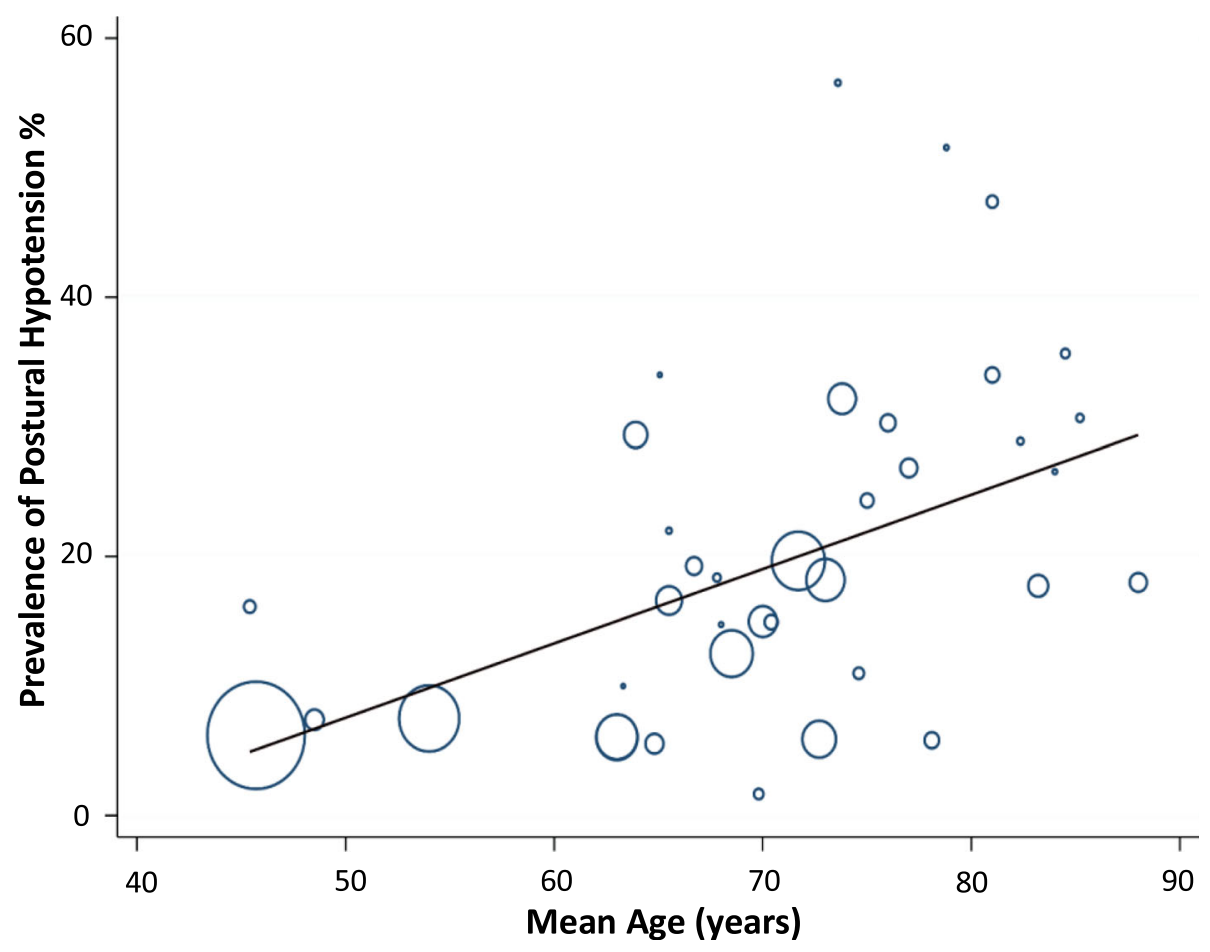

Fig. 7 Bubble plot of study level association between mean age and prevalence of postural hypotension according to the consensus definition (systolic $\geq 20 \mathrm{mmHg}$ or diastolic $\geq 10 \mathrm{mmHg}$ within three minutes of standing). Circles represent estimates from each study, sized according to precision of estimate

(indicating treatment) and absolute BP values. Exploration of such a relationship was not possible in the current analyses.

Current guidelines for postural hypotension management recommend clinicians undertake a comprehensive medication review if systolic BP falls by $20 \mathrm{mmHg}$ on standing [6]. The de-escalation of antihypertensive medication is a common treatment method and may increase the probability of recovery from postural hypotension with no increased risk of adverse cardiovascular events [87], however, further work in this area is required.

\section{Comparison with existing literature}

This review builds on existing reviews that have summarised prevalence of $\mathrm{PH}$ in specific cohorts, such as those with diabetes or Parkinson's disease and individuals over 60 years of age [13, 88-91]. Here, we report that PH affects $18 \%$ of individuals across care settings and disease cohorts. Our data show that $\mathrm{PH}$ incidence rises from community care settings to those attending primary care and residing in institutions. These findings reflect the likelihood that multimorbidity, and the subsequent risk of $\mathrm{PH}$, is more common in care/nursing home settings than general practices or in the community [92]. We also found that individuals with chronic disease have increased prevalence estimates of $\mathrm{PH}$ compared to groups without such diseases present. This may be due to a number of factors, including medication (e.g. diuretics, antihypertensives), development of peripheral and/or autonomic neuropathy (associated with diabetes mellitus and dementia) or physical deconditioning (due to age-related changes or continued bed rest) [4].

There appears to have been an exponential rise in interest in $\mathrm{PH}$, with $\sim 70 \%$ of the studies reported in this review published in the last decade and $\sim 50 \%$ in the last 5 years. This may reflect interest in rising longevity, multimorbidity and rates of diabetes (risk markers for PH) [93, 94]. Recent reporting of improved cardiovascular outcomes with intensive lowering of $\mathrm{BP}$ is also relevant $[95,96]$, given the risks of adverse events such as $\mathrm{PH}$ and falls, associated with lower BP targets [97].

Our findings are consistent with studies that have reported high prevalences of $\mathrm{PH}$ in individuals with diabetes (type 1, 19\% and type 2, 20\%) [88], and in the aged [98]. Prevalences approaching 50\% have been reported in Parkinson's disease with low prevalence of orthostatic symptoms, making the case for routine postural BP testing when reviewing all sufferers [99].

On subgroup analyses, we found no significant difference in $\mathrm{PH}$ prevalence when measuring $\mathrm{BP}$ in the sitting position rather than supine, prior to standing, and this finding remained on exclusion of low quality studies. This approach may therefore be justified as 
an alternative to the gold-standard supine-to-stand approach, if undertaken with rigid methodology. Shaw et al. have previously suggested that the sit-to-stand method is a good alternative for busy clinicians when the supine-to-standing method cannot be achieved; they proposed reducing diagnostic thresholds for $\mathrm{PH}$ to a systolic drop $\geq 15 \mathrm{mmHg}$ or a diastolic drop $\geq 7 \mathrm{mmHg}$ to maximise the sensitivity and specificity of the test and to reflect the reduced orthostatic stress of moving from sitting to standing, compared with lying supine [100]. We found no evidence to support a change in diagnostic threshold in this review, but suggest future studies should directly compare supine versus seated followed by standing $\mathrm{PH}$ measurement methods. We also found that adopting auscultatory or oscillometric methods of measuring BP did not impact prevalence estimates. Further work is required across larger cohorts to determine the most appropriate diagnostic criteria for $\mathrm{PH}$ in primary care if the pragmatic sit-tostand method is to be adopted.

When the definition of $\mathrm{PH}$ did not fulfil the consensus description, but fell within its parameters, we found that prevalence was underestimated irrespective of study quality. This highlights the importance of adopting the consensus definition to minimise under-detection of $\mathrm{PH}$ whenever possible [1].

\section{Implications for research and/or practice}

Our univariable regression analyses confirmed that an increasing $\mathrm{PH}$ prevalence is strongly associated with increasing age, with age-related chronic diseases and with previous falls. Multivariable analyses revealed that increasing age and presence of diabetes were particularly associated with increased PH prevalence; such individuals may benefit from routine checking for postural hypotension. The population is aging [101], and people are living for longer periods in older age with levels of dependency, or in care settings [102]. European hypertension guidelines, recommend checking for $\mathrm{PH}$ in older people, and this will include greater numbers, with attendant workload pressures, over time $[7,16]$. By describing the commonly encountered disease states and care settings associated with higher than background prevalences of $\mathrm{PH}$, we provide evidence to encourage improved recognition of this condition through targeted testing. Ideally, BP should ideally be measured from supine to standing using auscultatory methods and our results support the use of the consensus definition $[1,80]$. Pragmatically, however, the sit-to-stand method may also be employed as an alternative to the gold standard if the methods are rigorous [100]. However, further work comparing supine versus seated followed by standing measurement methods should be undertaken to clarify the most approach resting positions and thresholds for accurate $\mathrm{PH}$ diagnosis.

\section{Conclusion}

Overall, these findings demonstrate the substantial prevalence of $\mathrm{PH}$ across a range of populations and care settings relevant to primary care. Our prevalence findings suggest that checking for the presence of $\mathrm{PH}$ should be routinely considered when treating chronic conditions, such as diabetes, particularly in older persons. Failure to follow the consensus definition of $\mathrm{PH}$ appears to underestimate prevalence, therefore we advocate adoption of the consensus as a standard whenever checking for $\mathrm{PH}$. Further work is needed to confirm the diagnostic thresholds for postural hypotension when $\mathrm{BP}$ is measured in the seated rather than supine position.

\section{Appendix 1}

\section{Search strategy (Medline and Embase)}

1 postural hypotension.mp. [mp $=\mathrm{ti}, \mathrm{ab}, \mathrm{hw}, \mathrm{tn}, \mathrm{ot}, \mathrm{dm}$, $\mathrm{mf}, \mathrm{dv}, \mathrm{kw}, \mathrm{fx}, \mathrm{nm}, \mathrm{kf}, \mathrm{px}, \mathrm{rx}, \mathrm{ui}, \mathrm{sy}]$

2 orthostatic hypotension.mp. [ $\mathrm{mp}=\mathrm{ti}, \mathrm{ab}, \mathrm{hw}, \mathrm{tn}$, ot, $\mathrm{dm}, \mathrm{mf}, \mathrm{dv}, \mathrm{kw}, \mathrm{fx}, \mathrm{nm}, \mathrm{kf}, \mathrm{px}, \mathrm{rx}, \mathrm{ui}, \mathrm{sy}]$

3 prevalence.mp. [mp $=\mathrm{ti}, \mathrm{ab}, \mathrm{hw}, \mathrm{tn}, \mathrm{ot}, \mathrm{dm}, \mathrm{mf}, \mathrm{dv}$, $\mathrm{kw}, \mathrm{fx}, \mathrm{nm}, \mathrm{kf}, \mathrm{px}, \mathrm{rx}, \mathrm{ui}, \mathrm{sy}]$

1 or 2

3 and 4

Limit 5 to human

\section{Appendix 2}

Newcastle-Ottawa Scale adapted for cross-sectional studies for review of postural hypotension prevalence

Selection: (Maximum 5 stars (5 points))

Covidence key: 0 stars $=$ High ROB

1 or 2 stars $=$ Low $\mathrm{ROB}$

Cannot tell $=$ Unclear $\mathrm{ROB}$

1) Representativeness of the sample:

a) Truly representative of the average in the target population. " (all subjects or random sampling)

b) Somewhat representative of the average in the target population. " (non-random sampling)

c) Selected group of users.

d) No description of the sampling strategy.

2) Sample size:

a) Justified and satisfactory (a subjective judgement). *

b) Not justified (important mainly if low sample size e.g. < 100).

3) Non-participants:

a) Comparability between respondents and nonrespondents characteristics is established, and the response rate is satisfactory. *

b) The response rate is unsatisfactory, or the comparability between respondents and nonrespondents is unsatisfactory. 
c) No description of the response rate or the characteristics of the responders and the nonresponders.

4) Ascertainment of the exposure (i.e. measurement of sitting/lying and standing blood pressure):

a) Validated measurement tool. **:

b) Non-validated measurement tool, but the tool is available or described."

c) No description of the measurement tool.

\section{Comparability: (Maximum 2 points)}

1) The subjects in different outcome groups are comparable, based on the study design or analysis. Confounding factors are controlled. In this context it is controlling for co-variates.

Reported prevalence may be reported as unadjusted (usual) with logistic regressions or adjusted. Can indicate which in extraction. Go for unadjusted or adjusted?

a) The study controls for the most important factor (systolic BP or Age probably both important). *

b) The study control for any additional factor (candidates include BMI, BP, age, gender use of antihypertensive medication). *

Outcome: (Maximum 3 stars)

The outcome for this review is the prevalence of postural hypotension:

1) Assessment of the outcome:

a) Independent blind assessment. **

b) Record linkage. **

c) Self report. *

d) No description.

These descriptors are unhelpful so suggest re-classify as:

a) presented as $n / N$ or proportion for each relevant group in results. **

b) Self report i.e. in some way reported by unblinded investigators. *

c) No description

2) Statistical test:

In this review - the calculation of proportion(s) with postural hypotension, so should be clearly derived from $\mathrm{n} / \mathrm{N}$ without unexpected or unexplained omissions from numerator or denominator. a) The statistical test used to analyze the data is clearly described and appropriate, and the measurement of the association is presented, including confidence intervals and the probability level ( $p$ value)."

b) The statistical test is not appropriate, not described or incomplete.

\section{Abbreviations}

PH: Postural hypotension; BP: Blood pressure; NOS: Newcastle-Ottawa Scale

\section{Acknowledgements}

We thank Mrs. Ellie Kingsland for administrative support in retrieving many of the papers included in this review.

\section{Authors' contributions}

CEC and SM conceived this study, undertook searching, study selection, data extractions, quality assessment, carried out the analysis and drafted the manuscript. NM undertook searching, study selection and data extractions. All authors contributed to and approved the final version of the manuscript for publication.

Funding

Not applicable.

Availability of data and materials

The datasets used and/or analysed during the current study are available from the corresponding authors on reasonable request.

Ethics approval and consent to participate

Not applicable.

Consent for publication

Not applicable.

Competing interests

Not applicable.

Received: 26 June 2020 Accepted: 12 November 2020

Published online: 02 January 2021

\section{References}

1. Freeman R, Wieling W, Axelrod FB, Benditt DG, Benarroch E, Biaggioni I, et al. Consensus statement on the definition of orthostatic hypotension, neurally mediated syncope and the postural tachycardia syndrome. Clin Auton Res. 2011:21(2):69-72.

2. Juraschek SP, Daya N, Appel LJ, Miller IIIER, Windham BG, Pompeii L, et al. Orthostatic hypotension in middle-age and risk of falls. Am J Hypertens. 2017;30(2):188-95.

3. Mehrabian S, Duron E, Labouree F, Rollot F, Bune A, Traykov L, et al. Relationship between orthostatic hypotension and cognitive impairment in the elderly. J Neurol Sci. 2010;299(1-2):45-8.

4. Biaggioni I, Norcliffe-Kaufmann, L., \& Kaufmann, H Orthostatic hypotension 2016. Available from: http://bestpractice.bmj.com/best-practice/monograph/ 972.html. Accessed 14 Aug 2017.

5. Benvenuto $L$, Krakoff $L R$. Morbidity and mortality of orthostatic hypotension: implications for management of cardiovascular disease. [review]. Am J Hypertens. 2011;24(2):135-44.

6. National Institute for Health and Care Excellence; Hypertension in adults: diagnosis and management (CG127). 2011.

7. Williams B, Mancia G, Spiering W, Agabiti Rosei E, Azizi M, Burnier M, et al. 2018 ESC/ESH guidelines for the management of arterial hypertension. Eur Heart J. 2018:39(33):3021-104.

8. Mejzner N, Clark CE, Smith LF, Campbell JL. Trends in the diagnosis and management of hypertension: repeated primary care survey in south West England. Br J Gen Pract. 2017;67(658):e306-e13. 
9. Rutan GH, Hermanson B, Bild DE, Kittner SJ, LaBaw F, Tell GS. Orthostatic hypotension in older adults. The cardiovascular health study. CHS collaborative research group. Hypertension. 1992;19(6 Pt 1):508-19.

10. Clara JG, De Macedo ME, Pego M. Prevalence of isolated systolic hypertension in the population over 55 years old. Results from a national study. Rev Port Cardiol. 2007;26(1):11-8.

11. Cohen G, Zalomonson S, Press Y. Prevalence of orthostatic hypotension in the unselected ambulatory population of persons aged 65 years old and above. Blood Press. 2015;24(5):03.

12. Naschitz JE, Slobodin G, Elias N, Rosner I. The patient with supine hypertension and orthostatic hypotension: a clinical dilemma. Postgrad Med J. 2006;82(966):246-53.

13. Winkler AS, Bosman DR. Symptomatic postural hypotension in diabetes: Aetiology and management. Pract Diabetes Int. 2003;20(6):219-25.

14. Clark CE, Thomas D, Warren FC, Llewellyn DJ, Ferrucci L, Campbell JL. Detecting risk of postural hypotension (DROP): derivation and validation of a prediction score for primary care. BMJ Open. 2018;8(4):e020740.

15. Hale WA, Chambliss ML. Should primary care patients be screened for orthostatic hypotension? J Fam Pract. 1999;48(7):547-52.

16. Hobbs FD, Bankhead C, Mukhtar T, Stevens S, Perera-Salazar R, Holt T, et al. Clinical workload in UK primary care: a retrospective analysis of 100 million consultations in England, 2007-14. Lancet. 2016;387(10035):2323-30.

17. Phillips LS, Branch WT, Cook CB, Doyle JP, El Kebbi IM, Gallina DL, et al. Clinical inertia. Ann Intern Med. 2001;135(9):825-34.

18. Excellence NIfHaC. Falls in older people: assessing risk and prevention clinical guideline (CG161). 2013

19. Nyaga VN, Arbyn M, Aerts M. Metaprop: a Stata command to perform metaanalysis of binomial data. Arch Public Health. 2014;72(1):39.

20. Harbord R, Higgins JPT. Meta-regression in Stata. Stata J. 2008;8(4):493-519.

21. Egger M, Smith GD, Schneider M, Minder C. Bias in meta-analysis detected by a simple, graphical test. BMJ. 1997;315(7109):629-34

22. Hommel A, Faber M, Weerkamp N, van Dijk J, Bloem B, Koopmans R. Prevalence and prescribed treatments of orthostatic hypotension in institutionalized patients with Parkinson's disease. J Parkinsons Dis. 2016;6(4):805-10.

23. Enrique AL, Andrea AC, Maria de los Angeles C, Mendoza CKL, Nava DPE, Ana Lilia RC, et al. Prevalence of orthostatic hypotension in a series of elderly Mexican institutionalized patients. Cardiol J. 2011;18(3):2011.

24. Valbusa F, Labat C, Salvi P, Vivian ME, Hanon O, Benetos A. Orthostatic hypotension in very old individuals living in nursing homes: The PARTAGE study. J Hypertens. 2012;30(1):53-60.

25. Bouhanick B, Meliani S, Doucet J, Bauduceau B, Verny C, Chamontin B, et al. Orthostatic hypotension is associated with more severe hypertension in elderly autonomous diabetic patients from the French Gerodiab study at inclusion. Ann Cardiol Angeiol. 2014;63(3):176-82.

26. Fleg JL, Evans GW, Margolis KL, Barzilay J, Basile JN, Bigger JT, et al. Orthostatic hypotension in the ACCORD (action to control cardiovascular risk in diabetes) blood pressure trial: prevalence, incidence, and prognostic significance. Hypertension. 2016;68(4):888-95.

27. Hirai FE, Moss SE, Klein BE, Klein R. Postural blood pressure changes and associated factors in long-term type 1 diabetes: Wisconsin epidemiologic study of diabetic retinopathy. J Diabetes Complicat. 2009;23(2):83-8.

28. Klanbut S, Phattanarudee S, Wongwiwatthananukit S, Suthisisang C, Bhidayasiri R. Symptomatic orthostatic hypotension in Parkinson's disease patients: prevalence, associated factors and its impact on balance confidence. J Neurol Sci. 2018;385:168-74.

29. Kleipool EEF, Trappenburg MC, Rhodius-Meester HFM, Lemstra AW, van der Flier WM, Peters MJL, et al. Orthostatic hypotension: an important risk factor for clinical progression to mild cognitive impairment or dementia. The Amsterdam dementia cohort. J Alzheimers Dis. 2019:71(1):317-25.

30. Merola A, Romagnolo A, Rosso M, Lopez-Castellanos JR, Wissel BD, Larkin S, et al. Orthostatic hypotension in Parkinson's disease: does it matter if asymptomatic? Parkinsonism Relat Disord. 2016;33:65-71.

31. Romagnolo A, Zibetti M, Merola A, Canova D, Sarchioto M, Montanaro E, et al. Cardiovascular autonomic neuropathy and falls in Parkinson disease: a prospective cohort study. J Neurol. 2019;266(1):85-91.

32. Sonnesyn H, Nilsen DW, Rongve A, Nore S, Ballard C, Tysnes OB, et al. High prevalence of orthostatic hypotension in mild dementia. Dement Geriatr Cogn Disord. 2009;28(4):307-13.

33. Wecht JM, Weir JP, Martinez S, Eraifej M, Bauman WA. Orthostatic hypotension and orthostatic hypertension in American veterans. Clin Auton Res. 2016;26(1):49-58.
34. Alli C, Avanzini F, Bettelli G, Colombo F, Corso R, Di TM, et al. Prevalence and variability of orthostatic hypotension in the elderly. Results of the 'Italian study on blood pressure in the elderly (SPAA)'. Eur Heart J. 1992;13(2):1992.

35. Atli T, Keven K. Orthostatic hypotension in the healthy elderly. Arch Gerontol Geriatr. 2006:43(3):313-7.

36. Bengtsson-Lindberg M, Larsson V, Minthon L, Wattmo C, Londos E. Lack of orthostatic symptoms in dementia patients with orthostatic hypotension. Clin Auton Res. 2015;25(2):87-94.

37. Hiorth YH, Pedersen KF, Dalen I, Tysnes OB, Alves G. Orthostatic hypotension in Parkinson disease: a 7-year prospective population-based study. Neurology. 2019;93(16):e1526-e34.

38. Kamaruzzaman S, Watt H, Carson C, Ebrahim S. The association between orthostatic hypotension and medication use in the British Women's Heart and Health Study. Age Ageing. 2010;39(1):afp192.

39. Liepelt-Scarfone I, Pilotto A, Muller K, Bormann C, Gauss K, Wurster I, et al. Autonomic dysfunction in subjects at high risk for Parkinson's disease. J Neurol. 2015;262(12):2643-52.

40. Liu K, Wang S, Wan S, Zhou Y, Pan P, Wen B, et al. Arterial Stiffness, Central Pulsatile Hemodynamic Load, and Orthostatic Hypotension. J Clin Hypertens (Greenwich). 2016;18(7):655-62.

41. Masuo K, Mikami H, Ogihara T, Tuck ML. Changes in frequency of orthostatic hypotension in elderly hypertensive patients under medications. Am J Hypertens. 1996:9(3):263-8.

42. Oishi E, Sakata S, Tsuchihashi T, Tominaga M, Fujii K. Orthostatic Hypotension Predicts a Poor Prognosis in Elderly People with Dementia. Int Med. 2016;55(15):1947-52.

43. Perez-Orcero A, Vinyoles-Bargallo E, Pujol-Ribera E, de la Figuera-von Wichmann M, Baena-Diez JM, Manjon-Villanueva R, et al. Prevalence of orthostatic hypotension in non-institutionalised elderly aged 80 and over. A diagnostic study using an oscillometric device. Hipertens y riesgo Vasc. 2016;33(3):93-102.

44. van Hateren KJJ, Kleefstra N, Blanker MH, Ubink-Veltmaat LJ, Groenier KH, Houweling ST, et al. Orthostatic hypotension, diabetes, and falling in older patients: a cross-sectional study. Br J Gen Pract. 2012;62(603):e696-702.

45. Walczak M. The prevalence of orthostatic hypotension in high-risk ambulatory elders. J Gerontol Nurs. 1991;17(11):26-9.

46. Zhu QO, Tan CS, Tan HL, Wong RG, Joshi CS, Cuttilan RA, et al. Orthostatic hypotension: prevalence and associated risk factors among the ambulatory elderly in an Asian population. Singap Med J. 2016;57(8):444-51.

47. Cremer A, Soumare A, Berr C, Dartigues JF, Gabelle A, Gosse P, et al. Orthostatic hypotension and risk of incident dementia: results from a 12-year follow-up of the Three-City study cohort. Hypertension. 2017;70(1):44-9.

48. Drozdz T, Bilo G, Debicka-Dabrowska D, Klocek M, Malfatto G, Kielbasa G, et al. Blood pressure changes in patients with chronic heart failure undergoing slow breathing training. Blood Press. 2016;25(1):4-10.

49. Foster-Dingley JC, Moonen JEF, de Ruijter W, van der Mast RC, van der Grond J. Orthostatic hypotension in older persons is not associated with cognitive functioning, features of cerebral damage or cerebral blood flow. J Hypertens. 2018;36(5):1201-6.

50. Hiitola P, Enlund H, Kettunen R, Sulkava R, Hartikainen S. Postural changes in blood pressure and the prevalence of orthostatic hypotension among homedwelling elderly aged 75 years or older. J Hum Hypertens. 2009;23(1):2009.

51. Kartheek BR, Kumar G. Postural changes in blood pressure in an elderly population. Int J Pharm Sci Rev Res. 2011;11(2):109-14.

52. Mendez AS, Melgarejo JD, Mena LJ, Chavez CA, Gonzalez AC, Boggia J, et al. Risk factors for orthostatic hypotension: differences between elderly men and women. Am J Hypertens. 2018;31(7):797-803.

53. Nguyen TT, Nguyen Van T, Nguyen QT, Nguyen TLT. Determining the prevalence of orthostatic hypotension and its associations with hypertension and functional decline in the community-dwelling elderly in Vietnam. J Clin Gerontol Geriatr. 2017:8:88-92.

54. Putnam HWI, Jones R, Rogathi J, Gray WK, Swai B, Dewhurst M, et al. Hypertension in a resource-limited setting: is it associated with end organ damage in older adults in rural Tanzania? J Clin Hypertens (Greenwich). 2018;20(2):217-24

55. Rockwood MR, Howlett SE, Rockwood K. Orthostatic hypotension $(\mathrm{OH})$ and mortality in relation to age, blood pressure and frailty. Arch Gerontol Geriatr. 2012;54(3):e255-e60.

56. Veronese N, Bolzetta F, De RM, Zambon S, Corti MC, Musacchio E, et al. Serum 25-hydroxyvitamin D and orthostatic hypotension in old people: The Pro.V.A. study. Hypertension. 2014;64(3):481-6. 
57. Wolters FJ, Mattace-Raso FU, Koudstaal PJ, Hofman A, Ikram MA. Orthostatic hypotension and the long-term risk of dementia: a population-based study. PLoS Med. 2016;13(10):e1002143.

58. Assantachai P, Watanapa W, Chiempittayanuwat S, Thipanunt P. Hypertension in the elderly: a community study. J Med Assoc Thailand. 1998:81(4):243-9.

59. Bell EJ, Agarwal SK, Cushman M, Heckbert SR, Lutsey PL, Folsom AR. Orthostatic hypotension and risk of venous thromboembolism in 2 cohort studies. Am J Hypertens. 2016;29(5):634-40.

60. Cilia R, Cereda E, Klersy C, Canesi M, Zecchinelli AL, Mariani CB, et al. Parkinson's disease beyond 20 years. J Neurol Neurosurg Psychiatry. 2015; 86(8):849-55.

61. Curreri C, Giantin V, Veronese N, Trevisan C, Sartori L, Musacchio E, et al. Orthostatic changes in blood pressure and cognitive status in the elderly: the Progetto Veneto Anziani study. Hypertension. 2016;68(2):427-35.

62. Ensrud KE, Nevitt MC, Yunis C, Hulley SB, Grimm RH, Cummings SR. Postural hypotension and postural dizziness in elderly women: the study of osteoporotic fractures. Arch Intern Med. 1992;152(5):1992.

63. Fan XH, Wang Y, Sun $\mathrm{K}$, Zhang W, Wang H, Wu H, et al. Disorders of orthostatic blood pressure response are associated with cardiovascular disease and target organ damage in hypertensive patients. Am J Hypertens. 2010;23(8):829-37.

64. Fedorowski A, Stavenow L, Hedblad B, Berglund G, Nilsson PM, Melander O. Orthostatic hypotension predicts all-cause mortality and coronary events in middle-aged individuals (the Malmo preventive project). Eur Heart J. 2010; 31(1):85-91.

65. Frewen J, Savva GM, Boyle G, Finucane C, Kenny RA. Cognitive performance in orthostatic hypotension: Findings from a nationally representative sample. J Am Geriatr Soc. 2014;62(1):117-22.

66. Gangavati A, Hajjar I, Quach L, Jones RN, Kiely DK, Gagnon P, et al, Hypertension, orthostatic hypotension, and the risk of falls in a communitydwelling elderly population: the maintenance of balance, independent living, intellect, and zest in the elderly of Boston study. [erratum appears in J Am Geriatr Soc. 2011 May;59(5):960]. J Am Geriatr Soc. 2011;59(3):383-9.

67. Lampela P, Lavikainen P, Huupponen R, Leskinen E, Hartikainen S. Comprehensive geriatric assessment decreases prevalence of orthostatic hypotension in older persons. Scand J Public Health. 2013;41(4):351-8.

68. Luukinen H, Koski K, Laippala P, Kivela SL. Prognosis of diastolic and systolic orthostatic hypotension in older persons. Arch Intern Med. 1999;159(3):08.

69. Luukkonen A, Tiihonen M, Rissanen T, Hartikainen S, Nykanen I. Orthostatic hypotension and associated factors among home care clients aged 75 years or older - a population-based study. J Nutr Health Aging. 2018;22(1):154-8.

70. Mader SL, Josephson KR, Rubenstein LZ. Low prevalence of postural hypotension among community-dwelling elderly. J Am Med Assoc. 1987; 258(11):1987.

71. Masaki KH, Schatz IJ, Burchfiel CM, Sharp DS, Chiu D, Foley D, et al. Orthostatic hypotension predicts mortality in elderly men: the Honolulu heart program. Circulation. 1998;98(21):24.

72. O'Connell MDL, Savva GM, Fan CW, Kenny RA. Orthostatic hypotension, orthostatic intolerance and frailty: the Irish longitudinal study on aging-TILD A. Arch Gerontol Geriatr. 2015;60(3):01.

73. Ong HL, Abdin E, Seow E, Pang S, Sagayadevan V, Chang S, et al. Prevalence and associative factors of orthostatic hypotension in older adults: results from the well-being of the Singapore elderly (WiSE) study. Arch Gerontol Geriatr. 2017;72:146-52.

74. Shin C, Abbott RD, Lee H, Kim J, Kimm K. Prevalence and correlates of orthostatic hypotension in middle-aged men and women in Korea: The Korean Health and Genome Study. J Hum Hypertens. 2004;18(10):717-23.

75. Vanhanen $H$, Thijs L, Birkenhager W, Bulpitt C, Tilvis R, Sarti C, et al. Prevalence and persistency of orthostatic blood pressure fall in older patients with isolated systolic hypertension. J Hum Hypertens. 1996;10(9):1996.

76. Velilla-Zancada SM, Escobar-Cervantes C, Manzano-Espinosa L, Prieto-Diaz MA, Ramalle-Gomara E, Vara-Gonzalez LA. Impact of variations in blood pressure with orthostatism on mortality: the HOMO study. Blood Press Monit. 2017;22(4):184-90.

77. Viramo P, Luukinen H, Koski K, Laippala P, Sulkava R, Kivela SL. Orthostatic hypotension and cognitive decline in older people. J Am Geriatr Soc. 1999; 47(5):600-4.

78. Wu JS, Yang YC, Lu FH, Wu CH, Wang RH, Chang CJ. Populationbased study on the prevalence and risk factors of orthostatic hypotension in subjects with pre-diabetes and diabetes. Diabetes Care. 2009;32(1):69-74.
79. Yap PL, Niti M, Yap KB, Ng TP. Orthostatic hypotension, hypotension and cognitive status: early comorbid markers of primary dementia? Demen Geriatr Cogn Disord. 2008;26(3):239-46.

80. Iqbal P, Fotherby MD, Potter JF. Differences in orthostatic blood pressure changes measured with an oscillometric blood pressure monitor and a mercury sphygmomanometer. Blood Press. 1996;5(4):222-6.

81. Hartling L, Featherstone R, Nuspl M, Shave K, Dryden DM, Vandermeer B. Grey literature in systematic reviews: a cross-sectional study of the contribution of non-English reports, unpublished studies and dissertations to the results of meta-analyses in child-relevant reviews. BMC Med Res Methodol. 2017;17(1):64

82. Hartling L, Milne A, Hamm MP, Vandermeer B, Ansari M, Tsertsvadze A, et al. Testing the Newcastle Ottawa scale showed low reliability between individual reviewers. J Clin Epidemiol. 2013;66(9):982-93.

83. Goldstein DS, Pechnik S, Holmes C, Eldadah B, Sharabi Y. Association between supine hypertension and orthostatic hypotension in autonomic failure. Hypertension. 2003;42(2):136-42.

84. Di SC, Milazzo V, Bruno G, Maule S, Veglio F. Prevalence of orthostatic hypotension in a cohort of patients under antihypertensive therapy. High Blood Pressure and Cardiovascular PreventionConference: 2013 National Congress of the Italian Society of Hypertension, SIIA 2013 Rome ItalyConference Start: 20131003 Conference End: 20131005Conference Publication: (varpagings). 2013;20:3

85. Barochiner J, Alfie J, Aparicio L, Rada M, Morales M, Cuffaro P, et al. Orthostatic hypotension in treated hypertensive patients. Rom J Int Med. 2012, 2012;50(3):203-9.

86. Auseon A, Ooi WL, Hossain M, Lipsitz LA. Blood pressure behavior in the nursing home: Implications for diagnosis and treatment of hypertension. $J$ Am Geriatr Soc. 1999;47(3):285-90.

87. Moonen JEF, Foster-Dingley JC, de Ruijter W, van der Grond J, de Craen AJM, van der Mast RC. Effect of discontinuation of antihypertensive medication on orthostatic hypotension in older persons with mild cognitive impairment: the DANTE study Leiden. Age Ageing. 2016;45(2):249-55.

88. Zhou Y, Ke SJ, Qiu XP, Liu LB. Prevalence, risk factors, and prognosis of orthostatic hypotension in diabetic patients: a systematic review and metaanalysis. Medicine (Baltimore). 2017;96(36):e8004

89. Velseboer DC, de Haan RJ, Wieling W, Goldstein DS, de Bie RM. Prevalence of orthostatic hypotension in Parkinson's disease: a systematic review and meta-analysis. Parkinsonism Relat Disord. 2011;17(10):724-9.

90. Low PA. Prevalence of orthostatic hypotension. Clin Auton Res. 2008; 18(Suppl 1):8-13.

91. Nlz S, Pin Tan M, Frith J. The Prevalence of Orthostatic Hypotension: A Systematic Review and Meta-Analysis; 2018.

92. Schram MT, Frijters D, van de Lisdonk EH, Ploemacher J, de Craen AJ, de Waal MW, et al. Setting and registry characteristics affect the prevalence and nature of multimorbidity in the elderly. J Clin Epidemiol. 2008;61(11): 1104-12.

93. Office for National Statistics. National Population Projections: 2016-based statistical bulletin 2016. Available from: www.ons.gov.uk.

94. Klonoff DC. The increasing incidence of diabetes in the 21st century. Jiabetes Sci Technol. 2009:3(1):1-2

95. Leung AA, Nerenberg K, Daskalopoulou SS, McBrien K, Zarnke KB, Dasgupta K, et al. Hypertension Canada's 2016 Canadian hypertension education program guidelines for blood pressure measurement, diagnosis, assessment of risk, prevention, and treatment of hypertension. Can J Cardiol. 2016;32(5): 569-88

96. Gabb GM, Mangoni AA, Anderson CS, Cowley D, Dowden JS, Golledge J, et al. Guideline for the diagnosis and management of hypertension in adults - 2016. Med J Aust. 2016;205(2):85-9.

97. Clark CE, McManus R. The use of highly structured care to achieve blood pressure targets. BMJ. 2012;345:e7777.

98. Finucane C, O'Connell MD, Fan CW, Savva GM, Soraghan CJ, Nolan H, et al. Age-related normative changes in phasic orthostatic blood pressure in a large population study: findings from the Irish longitudinal study on ageing (TILDA). Circulation. 2014;130(20):11

99. Palma JA, Gomez-Esteban JC, Norcliffe-Kaufmann L, Martinez J, Tijero B, Berganzo K, et al. Orthostatic hypotension in Parkinson disease: how much you fall or how Low you go? Mov Disord. 2015:30(5):15.

100. Shaw BH, Garland EM, Black BK, Paranjape SY, Shibao CA, Okamoto LE, et al. Optimal diagnostic thresholds for diagnosis of orthostatic hypotension with a 'sit-to-stand test'. J Hypertens. 2017;35(5):1019-25. 
101. Global, regional, and national age-sex specific all-cause and cause-specific mortality for 240 causes of death, 1990-2013: a systematic analysis for the Global Burden of Disease Study 2013. Lancet (London). 2015;385(9963):117-71.

102. Kingston A, Wohland P, Wittenberg R, Robinson L, Brayne C, Matthews FE,

et al. Is late-life dependency increasing or not? A comparison of the cognitive function and ageing studies (CFAS). Lancet. 2017;390(10103): 1676-84.

\section{Publisher's Note}

Springer Nature remains neutral with regard to jurisdictional claims in published maps and institutional affiliations.

Ready to submit your research? Choose BMC and benefit from:

- fast, convenient online submission

- thorough peer review by experienced researchers in your field

- rapid publication on acceptance

- support for research data, including large and complex data types

- gold Open Access which fosters wider collaboration and increased citations

- maximum visibility for your research: over $100 \mathrm{M}$ website views per year

At BMC, research is always in progress.

Learn more biomedcentral.com/submissions 